Universidade de Brasília - UnB

Centro de Excelência em Turismo - CET/UnB

Pós-Graduação Lato Sensu

Curso de Especialização em Gestão de Negócios em Turismo

MEIOS DE HOSPEDAGEM E DESENVOLVIMENTO SUSTENTÁVEL

Priscila de Souza Valente

Orientadora: Ariádne Pedra Bittencourt 


\title{
MEIOS DE HOSPEDAGEM E DESENVOLVIMENTO SUSTENTÁVEL
}

\author{
Priscila de Souza Valente
}

\section{Orientadora: Ariádne Pedra Bittencourt}

Monografia apresentada ao Centro de Excelência em Turismo - CET, da Universidade de Brasília - UnB, como requisito parcial à obtenção do grau de Especialista em Gestão de Negócios em Turismo.

Brasília-DF

UnB

2007 
Valente, Priscila.

Meios de Hospedagem e Desenvolvimento Sustentável / Priscila Valente - Brasília, 2007. 68 f. : il.

Monografia (especialização) - Universidade de Brasília, Centro de Excelência em Turismo, 2007.

Orientadora: Ariádne Pedra Bittencourt.

1. Sustentabilidade. 2. Desenvolvimento Sustentável. 3. Hotelaria. 
Universidade de Brasília - UnB

Centro de Excelência em Turismo - CET/UnB

Pós-Graduação Lato Sensu

Curso de Especialização em Gestão de Negócios em Turismo

Priscila de Souza Valente

Aprovado por:

Professora Orientadora: Ariadne Pedra Bittencourt

Titulação: Mestre

Professora: lara Brasileiro

Professor: Rogério Dias

Monografia apresentada ao Centro de Excelência em Turismo - CET, da Universidade de Brasília - UnB, como requisito parcial à obtenção do grau de Especialista em Gestão de Negócios em Turismo.

Brasília, 29 de maio de 2007. 


\section{AGRADECIMENTOS}

Agradeço primeiramente a Deus, e aos meus pais por terem me proporcionado tudo o que tenho até hoje na minha vida. Às minhas irmãs. Agradeço aos professores ao longo do curso, por compartilharem seus conhecimentos comigo. 
Todos têm o direito ao meio ambiente ecologicamente equilibrado, bem de uso comum do povo e essencial à sadia qualidade de vida, impondo-se ao Poder Público e à coletividade o dever de defendê-lo e preservá-lo para as presentes e futuras gerações. Para assegurar a efetividade desse direito, incumbe ao Poder Público, dentre outros mecanismos, promover a educação ambiental em todos os níveis de ensino e a conscientização pública para a preservação do meio ambiente.

Artigo 225 da Constituição Brasileira de 1988. 


\section{RESUMO}

O setor turístico é um dos seguimentos econômicos em maior ascensão do mundo, e cada vez se percebe a importância de seu potencial para promover o Desenvolvimento Sustentável, e minimizar os impactos causados no meio ambiente, na cultura, na economia e na comunidade local. Em Gestão de Meios de Hospedagem, um tema bastante abordado atualmente é o Desenvolvimento Sustentável. A aplicação de conhecimentos sobre sustentabilidade na hotelaria é uma tendência muito forte do mercado, o que gera diferencial competitivo, e cada vez mais faz com que o empresariado tenha atitudes ecologicamente corretas e respeite a cultura na qual está inserido. O público consumidor passa a exigir que as empresas dêem uma maior importância para a questão da preservação do meio ambiente, principalmente a atividade turística, pois esta é intimamente dependente da preservação do meio ambiente natural e cultural. O cuidado com a natureza, que antes era um diferencial, passou a ser pré-requisito do público no momento da escolha do meio de hospedagem. Este fator é responsável por um aumento na competitividade entre as empresas do setor hoteleiro como um todo. O presente estudo aborda os pontos fundamentais para a aplicação do desenvolvimento sustentável em meios de hospedagem, pontuando os procedimentos, ações, providências e precauções na gestão do empreendimento, utilizando-se como base o Desenvolvimento Sustentável. Geralmente a atividade turística envolve o ser humano e o ambiente que o cerca. Por isso é de fundamental importância que o meio ambiente seja preservado, para que o turismo possa ser feito com menos impacto possível para o meio ambiente da região onde o turismo está sendo realizado. Os atrativos naturais são o grande "produto" do turismo, concomitante aos atrativos culturais, que merecem tanta atenção. Porém, para aplicar os conceitos de desenvolvimento sustentável no processo de gestão, é necessário que seja economicamente viável para a organização, caso contrário não terá condições de sustentar-se no mercado. Esta pesquisa visou mostrar a importância da adoção de práticas sustentáveis em meios de hospedagem, e identificar ações que possam levar o empresário à gestão do empreendimento com base no Desenvolvimento Sustentável, possibilitando reduzir custos e otimizar os esforços, aliado à preservação da natureza e da cultura local. É fundamental que o gestor considere aspectos ambientais, econômicos, sociais, culturais e políticos.

Palavras-Chave: Sustentabilidade, Desenvolvimento Sustentável, Hotelaria. 


\section{ABSTRACT}

The tourist sector is one of the economic pursuings in bigger ascension of the world, and each time if perceives the importance of its potential to promote the Development Sustainable, and to minimize the impacts caused in the environment, the culture, the economy and the local community. In Hotel Management, a sufficiently boarded subject currently is the Sustainable Development. The application of knowledge on Sustainable Development in Hotel Management is a very strong trend of the market, what it generates competitive differential, and each time more makes businessmen have correct ecological attitudes and respects the culture in which is inserted. Costumers start to mainly demand that the companies give a bigger importance for the question of the preservation of the environment, the tourism activity, therefore this is very dependent of the preservation of the natural and cultural environment. The care with the nature, that before was a differential, started to be prerequisite of the costumers at the moment of choosing a hotel. This factor is responsable for an increase in the competitiveness between hotel companies sector as a whole. This study approaches the basic points for application of the sustainable development in hotels, checking the procedures, action, steps and precautions in the management it enterprise, using itself as base the Sustainable Development. Generally the tourism activity involves the human being and the environment that surrounds it. That is why is so important that the environment is preserved, so that the tourism can be made with the smallest impact as possible for the environment of the region where the tourism is being carried through. Natural attractives are the great "product" of the tourism, as well as cultural attractives, wich deserves as much attention as the natural ones. However, to apply the concepts of sustainable development in the management process, it is necessary that all of this is economically viable for the enterprise, or it will not have conditions to support itself in the market. This research aimed at to show the practical importance of the adoption of sustainable in Hotel Management, and to identify actions that can lead the businessman to a sustainable management of the enterprise, making possible to reduce costs and to optimize the efforts, with preservation of the nature and the local culture. It is important that the manager considers ambient, economic, social, cultural and politic aspects.

Keywords: Sustainable, Sustainable Development, Hotel Management. 


\section{LISTA DE ILUSTRAÇÕES}

Figura 1. Gráfico Consumo de Energia Tipo A......................................44

Figura 2. Gráfico Consumo de Energia Tipo B..............................................44

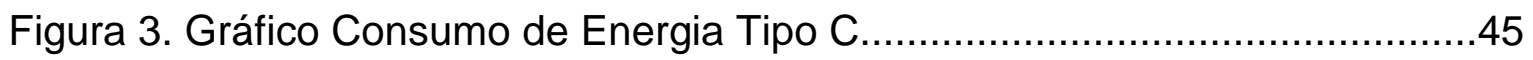

Figura 4. Gráfico Meta mínima e máxima consumo de Energia Tipo B................45

Figura 5. Gráfico Meta mínima e máxima consumo de Energia Tipo C..............46

Figura 6. Gráfico Reciclagem de Materiais Tipo B..........................................4

Figura 7. Gráfico Reciclagem de Materiais Tipo C.........................................47

Figura 8. Gráfico Dispositivos para economia de insumos Tipo B.......................48

Figura 9. Gráfico Dispositivos para economia de insumos Tipo C.......................49

Figura 10. Gráfico Tratamento especial para esgoto Tipo C...............................50

Figura 11. Gráfico Brigada de Incêndio Tipo B...............................................50

Figura 12. Gráfico Brigada de Incêndio Tipo C................................................

Figura 13. Gráfico Aquisição de Produtos Alimentícios Tipo B.............................52

Figura 14. Gráfico Aquisição de Produtos Alimentícios Tipo C.............................52

Figura 15. Gráfico Índice de Satisfação dos hóspedes Tipo B...............................53

Figura 16. Gráfico Envolvimento com a comunidade Tipo C..............................54

Figura 17. Gráfico Inserção Aspectos Culturais Tipo B....................................55 
ABIH: Associação Brasileira da Indústria Hoteleira

APEX-Brasil: Agência de Promoção de Exportação e Investimento

BID: Banco Interamericano de Desenvolvimento

C.B.T.S.: Conselho Brasileiro para o Turismo Sustentável

D.S.: Desenvolvimento Sustentável

IDEC: Instituto Brasileiro de Defesa do Consumidor

IAF: International Accreditation Forum

I.H.: Instituto de Hospitalidade

INMETRO: Instituto Nacional de Metrologia, Normalização e Qualidade Industrial

M.H.: Meios de Hospedagem

OMT: Organização Mundial do Turismo (WTO)

O.N.G.: Organização Não-Governamental

PCB: Bifenilas Policloradas

P.C.T.S.: Programa de Certificação em Turismo Sustentável

PROCEL: Programa de Combate ao Desperdício de Energia Elétrica

U.H.: Unidade Habitacional 


\section{SUMÁRIO}

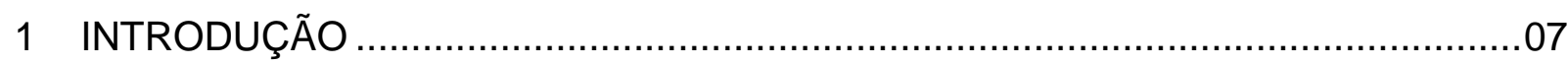

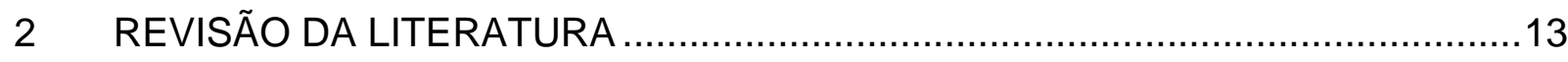

2.1 Turismo e Desenvolvimento Sustentável...................................................13

2.1.1 Certificação Ambiental do Turismo.......................................................19

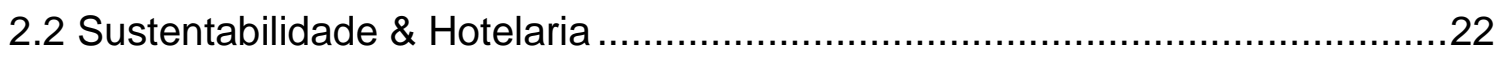

2.2.1 "Green Building" e Construção Sustentável............................................24

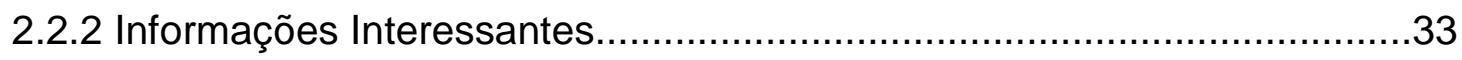

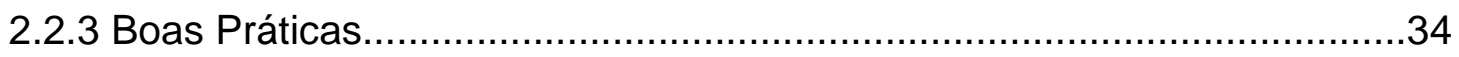

3 METODOLOGIA

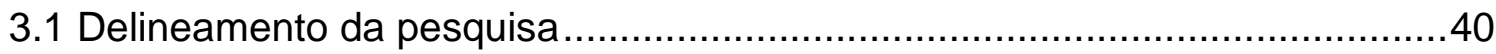

3.2 Área de interesse e população-alvo do estudo............................................

3.3 mostragem

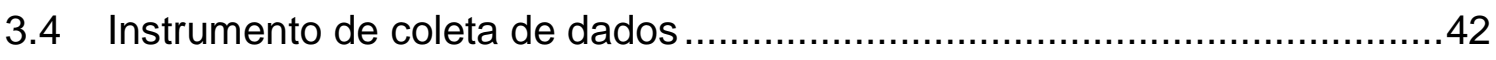

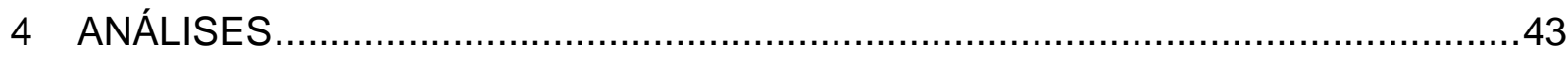

4.1 Tipo(s) de energia utilizado(s) pelos hotéis............................................43

4.2 Existência de metas para consumo de energia dos hotéis.........................45

4.3 Existência de sistema de coleta seletiva de lixo........................................46

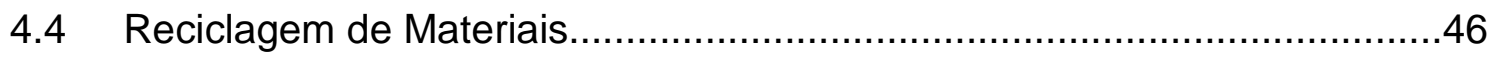

4.5 Reaproveitamento de água e gestão de seu uso.......................................48

4.6 Dispositivos para a economia de energia, água e outros insumos.............48

4.7 Controle do uso de produtos e embalagens descartáveis..........................49

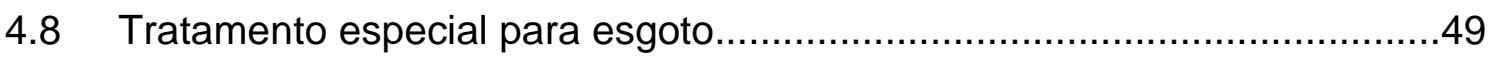




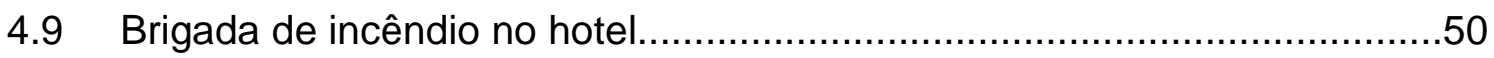

4.10 Aquisição de produtos alimentícios para o hotel.................................51

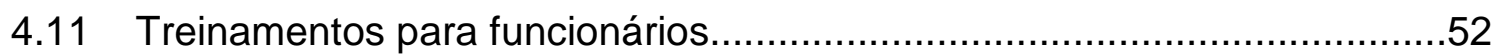

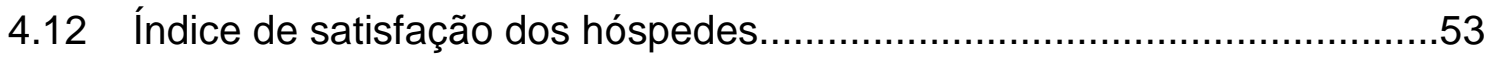

4.13 Programa de envolvimento com a comunidade.................................54

4.14 Envolvimento com projeto ou organização ecológica..............................54

4.15 Inserção de aspectos culturais no hotel e seus serviços..........................55

4.16 Visão sob aspecto econômico da preservação dos recursos naturais.......55

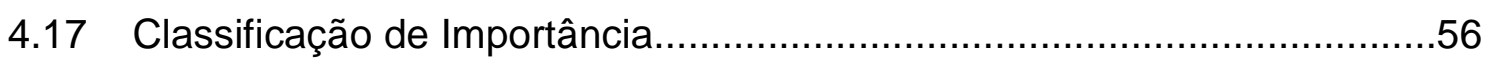

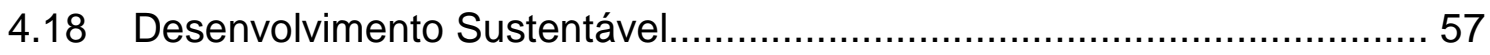

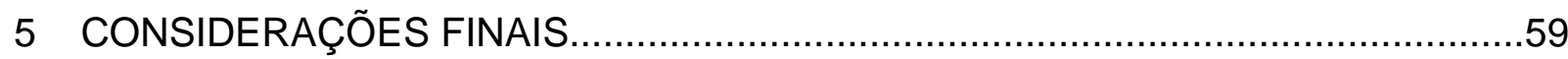

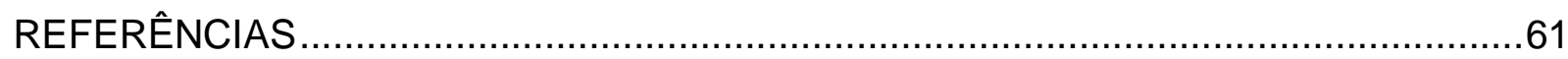

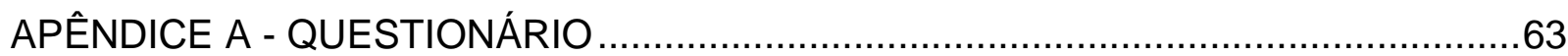

ANEXO A - Tabela ABIH-DF - Classificação dos Meios de Hospedagem/DF..............66

ANEXO B - Artigo - Bambu, o material nobre da construção ecológica........................67

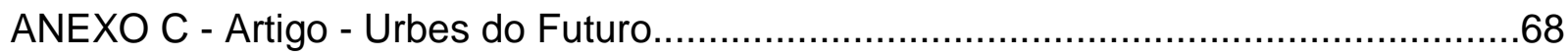




\section{INTRODUÇÃO}

O turismo é um dos seguimentos econômicos em maior ascensão do mundo, e cada vez mais sendo objeto de atenção de pesquisadores por seu potencial para promover o Desenvolvimento Sustentável, e minimizar os impactos causados no meio ambiente, na cultura, na economia e na comunidade local.

Na gestão hoteleira, um tema bastante abordado atualmente é o Desenvolvimento Sustentável no âmbito dos Meios de Hospedagem. A aplicação de conhecimentos sobre sustentabilidade no ramo hoteleiro predispõe uma tendência muito forte do mercado, e também um diferencial competitivo. As empresas estão cada vez mais preocupadas em demonstrar um desempenho correto em relação à sustentabilidade, gerindo os impactos causados por suas atividades, produtos e serviços, considerando sua política e seus objetivos de sustentabilidade.

O público consumidor passa a exigir que as empresas dêem uma maior importância para a questão da preservação do meio ambiente, principalmente a atividade turística, pois esta é intimamente dependente da preservação do meio ambiente natural e cultural.

O cuidado com a natureza, que antes era um diferencial que algumas empresas utilizavam, passou a ser pré-requisito do público no momento da escolha do meio de hospedagem no qual irá se hospedar. Este fator é responsável por um aumento na competitividade entre as empresas do setor hoteleiro como um todo. 
O mercado vem atualizando-se e muitos meios de hospedagem têm procurado especialistas que compreendam o conceito e a prática da sustentabilidade para, juntamente com a equipe do hotel, coordenar os vários setores do empreendimento para aplicar os princípios da sustentabilidade. Esse comportamento está relacionado a uma legislação cada vez mais exigente e à mudança de pensamento do consumidor.

Com isso, os hotéis pretendem economizar recursos naturais e financeiros, exercer sua responsabilidade social, ganhar notoriedade no setor, e reconhecimento por parte dos hóspedes, fornecedores, clientes, governo e da comunidade local.

A área de Desenvolvimento Sustentável é passível de vasto estudo. Porém, o estudo enfocará como, de forma eficaz, pode-se implantar a sustentabilidade em meios de hospedagem, porém através de um foco gerencial que considere concomitantemente os princípios da Administração de Empresas e as particularidades da Hotelaria.

O Turismo Sustentável deve ter por pilares: ser ambientalmente correto, economicamente viável, culturalmente respeitoso e socialmente justo.

Devemos encarar a Sustentabilidade como uma forma ótima de se desenvolver o turismo, avaliando os impactos por vários prismas diferentes.

A indústria da hospitalidade está extremamente ligada ao turismo, tanto que alguns órgãos encaram os dois como sendo um grande setor único. A hospitalidade, em seu conceito mais simples e objetivo, é a arte de servir e satisfazer os hóspedes. O serviço é tanto a missão quanto o produto da indústria da hospitalidade.

Porém, outros conceitos não podem ser descartados, e contribuem para fazer da hospitalidade algo maior: criar um ambiente agradável, uma atmosfera segura, an- 
tecipar os desejos dos hóspedes, recebê-los de maneira calorosa e cordial; criar experiências memoráveis por meio de serviços que supram suas necessidades.

Essas duas indústrias - hospitalidade e turismo - incluem uma gama de serviços: alimentos e bebidas, hospedagem, recreação, serviços relacionados a viagens, e produtos.

Na indústria da hospitalidade, um setor que está em constante ascensão é o turismo consciente ambientalmente, inclusive por iniciativa dos próprios consumidores, que cada vez mais se preocupam com as questões ambientais.

De acordo com Western (2002), ecoturismo envolve tanto um sério compromisso com a natureza quanto com a responsabilidade social. "A 'Ecotourism Society' oferece uma definição um pouco mais completa: ‘Ecoturismo é uma viagem responsável a áreas naturais, visando a preservar o meio ambiente e a promover o bem-estar da população local'" (WESTERN, 2002, p.17)

Segundo Chon (2003, p. 49), "quando planejado e administrado apropriadamente, o turismo pode contribuir para a preservação e a proteção do meio ambiente. (...) Muito turismo, ou turismo mal planejado, entretanto, pode resultar em poluição e danos ao meio ambiente".

O tema desenvolvido neste trabalho é "Desenvolvimento Sustentável em Meios de Hospedagem", onde são abordados os pontos fundamentais para a aplicação do conceito de desenvolvimento sustentável em meios de hospedagem, pontuando os procedimentos, ações, providências e precauções na gestão do empreendimento.

Geralmente a atividade turística envolve o ser humano e o ambiente que o cerca. Por isso é de fundamental importância que o meio ambiente seja preservado, para 
que o turismo possa ser feito de uma forma menos impactante para o meio ambiente da região onde está sendo realizado.

Os atrativos naturais são o grande carro-chefe do turismo, juntamente com atrativos culturais, que merecem tanta atenção quanto os recursos naturais, pois suas existências são intrínsecas.

A população tornou-se um público exigente e que faz ainda mais necessária a existência da gestão hoteleira aliada a sustentabilidade.

Atualmente o mercado cada vez mais impõe que o empresariado tenha atitudes ecologicamente corretas e respeite a cultura na qual sua empresa está inserida. Porém, para aplicar os conceitos de desenvolvimento sustentável no processo de gestão, é necessário que seja economicamente viável para a organização, caso contrário não terá condições de sustentar-se no mercado. Muitas empresas ainda desconhecem ou ignoram esta grande tendência de administração que alia eficácia empresarial e preservação da natureza, e pouco se percebe este diferencial competitivo para os meios de hospedagem.

Muitos hotéis têm interesse no Desenvolvimento Sustentável (D.S.) e estão começando a introduzir este novo modelo de gestão, de parceria entre hoteleiros e turismólogos/ecologistas. Mas não há mão-de-obra especializada em quantidade/qualidade para atender esta perspectiva de demanda aos hotéis que têm implantado algumas práticas de desenvolvimento sustentável. A pergunta de pesquisa é: A partir de que práticas um empreendimento hoteleiro pode ser sustentável ambientalmente, economicamente, socialmente e culturalmente? 
O objetivo geral da pesquisa é mostrar a importância da adoção de práticas sustentáveis em meios de hospedagem, identificando ações que possam levar o empresário à gestão do empreendimento com base no Desenvolvimento Sustentável, visando reduzir custos e otimizar os esforços, aliado à preservação da natureza e da cultura local.

Os objetivos específicos são:

a) Pesquisar em meios de hospedagem da cidade, para verificar se há aplicação de práticas de Desenvolvimento Sustentável;

b) Identificar ações que o gestor hoteleiro possa tomar para adequar seu empreendimento à sustentabilidade;

c) Identificar práticas de desenvolvimento sustentável, onde todas as ações são percebidas por um enfoque gerencial;

A justificativa para a realização do estudo está no mercado hoteleiro, que se encontra em franca expansão e devido a uma mudança no cenário mundial, tornou-se exigência do mercado a preocupação com a natureza e seus recursos. A Administração Hoteleira precisa se adequar às exigências da sociedade moderna, que se importa com a conservação e preservação do meio ambiente. Será uma tendência natural das empresas de buscar o Desenvolvimento Sustentável, e os meios de hospedagem deverão se adequar a esta nova realidade.

O interesse de desenvolver o projeto surgiu devido à necessidade de aprofundamento nas práticas de desenvolvimento sustentável que sejam voltadas a Administração em Hotelaria, mostrando ser um ramo muito promissor, e ser um assunto atual e extremamente relevante. 
Quanto à viabilidade, o projeto foi passível de realização, pois a pesquisa foi em grande parte bibliográfica e dados coletados in loco em diferentes hotéis da cidade, através de questionários, além de levantar também informações de cunho público.

A importância da pesquisa se deve à sua contribuição para empreendimentos que fazem ou pretendem fazer uso do Desenvolvimento Sustentável na Hotelaria, ou queiram aplicar parte de seus conceitos.

Por enfatizar visão gerencial sobre a aplicação do D.S. em hotéis, a pesquisa visa mostrar de forma holística as ações e benefícios que o D.S. pode trazer ao setor hoteleiro e ao meio ambiente. Com isso, o projeto se apresenta como um ponto de pesquisa para profissionais e empreendedores de hotelaria, e pessoas que se interessem pelo equilíbrio do meio ambiente, em geral. 


\section{REVISÃO DA LITERATURA}

2.1 Turismo e Desenvolvimento Sustentável

O turismo é uma das mais importantes atividades econômicas, que conecta os seres humanos uns com os outros e com o meio ambiente que os cerca.

Para Duarte (2003), turismo pode ser entendido como o resultado de um fenômeno social, econômico, político ou cultural, desencadeado pelo turista, que se desloca de seu local de residência, podendo ser por diversos motivos (lazer, negócios, tratamentos médicos, etc), permanecendo por, no mínimo, vinte e quatro horas nesta localidade.

O setor turístico cresce com grande velocidade, proporcionando geração de renda e trabalho, expansão do mercado, e avanço social e econômico para as mais diversas áreas. Sua natureza é multidisciplinar, reunindo conhecimento de diversas áreas, como geografia, arquitetura, administração, economia, sociologia, antropologia, marketing e comunicação (MONTORO, 2003).

O turismo pode proporcionar o desenvolvimento e a estabilidade da economia, sendo um dos fatores fundamentais para a melhoria da qualidade de vida.

De acordo com especialistas, a indústria do turismo será a grande solução de resposta imediata para as altas taxas de desemprego (BELTRÃO, 2001).

Assim, o turismo consiste em um grande sistema, que interliga vários elementos agentes e pacientes. Dentro deste sistema deve haver interação e organização, 
dada a complexidade de sistemas. Segundo Beni (2001), outros aspectos relevantes são: o modelo a ser implementado, o meio ambiente que influencia na operacionalização do sistema e o feedback (retroalimentação). E dentro das relações ambientais, deve-se atentar para os subsistemas: ecológico, social, econômico e cultural.

De acordo com a teoria de Maslow (1970 apud STEPHENS 2003), existe uma hierarquia de necessidades do ser humano, que vai desde as mais básicas, como as necessidades fisiológicas, passando por necessidades de segurança, sociais, e de estima, até a auto-realização. O turismo estaria nesta última instância, onde surgiria como um meio de satisfação humana.

O turismo envolve uma fuga física real, superando outras formas de lazer, que proporcionam fugas temporárias. Surgiu como uma fonte de crescimento ilimitado, e os setores envolvidos na indústria foram e adaptando às inovações, como as agências, operadoras, companhias aéreas, até o setor público, que tem no turismo um gerador de empregos, lucros, taxas, diversificação e desenvolvimento.

Para o turista em potencial se tornar um turista efetivo ele necessita de motivação para viajar, uma necessidade que parta de si mesmo, em busca de momentos que Ihe tragam satisfação pessoal. Podem ser criadas condições que favoreçam, ou até induzam, a pessoa a ter esse sentimento.

O turismo deve buscar o equilíbrio entre eficiência do crescimento econômico, igualdade na distribuição de renda e, ainda, respeitar o meio ambiente. Os fluxos turísticos podem trazer inúmeros benefícios, como geração de renda, empregos, elevação da qualidade de vida da população local, investimentos externos, criação de infraestrutura, envolvimento da comunidade, resgate da tradição local, conservação e de- 
senvolvimento da região; mas para isso é necessário definir estratégias de gestão sustentável e políticas públicas adequadas.

Os fluxos turísticos também podem trazer impactos negativos para o destino turístico, como degradação do meio ambiente, poluição, perda de biodiversidade, pressão sobre os recursos hídricos e energéticos, contaminação do solo, transformação da paisagem, preços mais elevados, desenvolvimento descontrolado do destino e seu comércio, mão-de-obra desqualificada, queda de qualidade dos serviços oferecidos, problemas com sazonalidade, alteração de costumes locais, dificuldade de comunicação, segregação e até hostilidades. As maiores preocupações são sempre com a natureza e seus recursos e com a comunidade local. Problemas mais graves como prostituição e exploração infantil no turismo, biopirataria e tráfico de drogas também surgem.

Em uma visão atual, é preciso que o planejamento da atividade turística se integre ao crescimento econômico e ao desenvolvimento sócio-cultural e ambiental.

O turismo sustentável pode ser definido como um processo completo - da divulgação correta da imagem ao alcance da satisfação, da permanência do turista até o regresso à origem. Ele envolve a conservação do local turístico e do meio ambiente natural e cultural com garantia de geração de melhores condições de vida à população local (MONTORO, 2003).

De acordo com a World Tourism Organization (2001), Organização Mundial do Turismo (OMT), o conceito de ecoturismo abrange todas as formas de turismo nas quais a maior motivação do turista é a observação e apreciação da natureza, o que contribui para sua conservação e minimiza impactos negativos nos ambientes natural e socio-cultural.

O turismo sustentável é uma atividade econômica de grande retorno e que abrange um público bem específico, que se identifica com a natureza e sua preservação, 
e também tem um bom poder aquisitivo. Segundo Beltrão (2001), no atual milênio, 10\% das atividades turísticas estarão direcionadas ao turismo ecológico, ou seja, abrange assim mais de 100 milhões de pessoas de todas as partes do planeta.

O contato com a natureza oferece uma gama de possibilidades para o ser humano, uma

\begin{abstract}
nova oportunidade de enfrentar emoções, as diferenças e os mistérios. Esse contato promove o resgate de sentimentos pessoais que foram esquecidos nesse processo de desenvolvimento da sociedade. Observe os vídeos e programas para a televisão sobre a vida selvagem: como eles fascinam as pessoas, sejam crianças ou adultos. Quantos seres os homens nem sabem que existem. Eles vivem suas vidas completamente indiferentes aos humanos! O ser humano não é tão importante assim! Criou-se um ambiente mais confortável, seguro e adequado para ele, mas a idéia de que é o ser mais importante do planeta simplesmente está na sua concepção. Não quer dizer que o mundo esteja de fato a serviço dele. (...) A experiência de estar na natureza pode ser um grande laboratório para a reformulação da questão da individualidade/individualismo nos processos coletivos: não se sabe que experiência poderia ser melhor do que essa para as pessoas se reumanizarem. (NEIMAN, 2002)
\end{abstract}

O conceito do turismo sustentável foi desenvolvido para evitar os riscos que a condução inadequada da atividade pode provocar no meio ambiente (RUSCHMANN, 2000). Foi a partir da Rio-92, a Conferência Mundial do Meio Ambiente e Desenvolvimento, que surgiu pela primeira vez a noção de Sustentabilidade (MONTORO, 2003).

No Brasil ainda os maiores destinos estão relacionados ao patrimônio natural do país. A exploração deste tipo de turismo deve ser bem consciente, pois as comunidades locais sofrem com a degradação da qualidade de seu ambiente, há perda de identidade cultural e os benefícios econômicos diminuem.

O Brasil tem grande oportunidade de se destacar no setor turístico mundial como um destino sustentável, que se preocupa com a utilização dos recursos naturais, com a conservação do patrimônio sócio-cultural do país e com a qualidade de vida das pessoas. 
Para aplicar os conceitos da sustentabilidade, deve-se considerar quatro aspectos de fundamental importância:

\section{Meio Ambiente}

Um dos assuntos mais importantes que a sociedade tem colocado em pauta atualmente é a conservação do meio ambiente, como forma de sobrevivência da espécie humana. O turismo deve ter como missão incentivar a preservação de recursos naturais, culturais e históricos, contribuindo para a sustentabilidade das áreas protegidas. Porém, sem o meio ambiente natural torna-se praticamente impossível a prática do turismo, pois é o grande atrativo da prática turística.

\section{Cultura}

O turismo consciente tem o poder de preservar e até resgatar culturas antigas, que estejam se perdendo. O turismo permite o resgate e o intercâmbio cultural.

A valorização da cultura, artesanato e gastronomia local pelo turismo constituem um grande produto turístico, capaz de movimentar um número enorme de turistas. Algumas localidades tiveram aumento do fluxo turístico devido à sua cultura, o que se for feito conscientemente, pode trazer vários benefícios para a comunidade. 


\section{Social}

Uma postura sustentável baseia-se em comportamentos ambientais corretamente relacionados, não somente com controle de água e lançamento indiscriminado de lixo nos lugares que visitam, mas também mantendo o respeito aos valores culturais das comunidades receptivas.

Cada vez mais existe consciência dos direitos e responsabilidades, inclusive com a destinação de terras para exploração turística. A desapropriação de moradores locais tornou-se uma questão determinante para a conservação. Porém, para isto, não se pode negar os direitos e interesses das comunidades locais. O turismo deve preservar a sociedade na qual está inserido, e não destruí-la.

Preservar o meio ambiente é fundamental para a continuidade da espécie humana, porém não se pode preservar a natureza às custas da população local. "Como responsáveis pela terra - como aqueles que mais podem perder com a conservação os moradores das comunidades locais devem participar do processo" (WESTERN, 2002, p. 16). Os empresários do ecoturismo costumam utilizar recursos e mão-de-obra local. Isso gera entrada de divisas do exterior, projetos adequados ao meio ambiente e inserção dos moradores da região.

Alguns benefícios são: aumento e diversificação da renda, ocupação da mãode-obra familiar relativamente ociosa, interação social e cultural com um público de alto nível social e educacional e aproveitamento racional de espaços ociosos. 


\section{Econômico}

Os benefícios do turismo vão além de resultados em termos de renda bruta ou líquida. Os países desenvolvidos têm mostrado cada vez mais interesse pelo ecoturismo, o que dá a dimensão do potencial deste setor. Os ecoturistas gastam bilhões de dólares todos os anos. (WESTERN, 2002)

Diminuir o desperdício é uma forma que, além de ajudar o meio ambiente, contribui significativamente para a redução de custos para uma organização.

\subsubsection{Certificação Ambiental do Turismo}

Diversas iniciativas têm sido desenvolvidas para promover o turismo sustentável. Entre elas, a criação de normas que estabeleçam os requisitos mínimos para o turismo sustentável, juntamente com mecanismos de certificação, que se destacam como tendências fortes no mercado internacional.

A certificação do turismo traz benefícios em várias esferas:

- Ambientalmente, contribui para a preservação da biodiversidade, ajuda na manutenção da qualidade do meio-ambiente dos atrativos turísticos e na proteção das fauna e flora locais;

- Economicamente, viabiliza as áreas usadas pelo turismo, gera vantagens competitivas para as empresas no campo do marketing e facilita o acesso a novos mercados, principalmente o internacional; 
- Social e culturalmente, promove boas condições de trabalho, enfatiza a preservação do patrimônio cultural e proporciona o respeito aos direitos dos trabalhadores, povos indígenas e comunidades locais; e

- Politicamente, promove o respeito à lei e à cidadania.

Existe o Programa de Certificação em Turismo Sustentável - PCTS, uma iniciativa liderada pelo Instituto de Hospitalidade, em parceria com o Conselho Brasileiro de Turismo Sustentável (CBTS) e apoio do BID (Banco Interamericano de Desenvolvimento), da Agência de Promoção de Exportações e Investimentos (APEX-Brasil), do Sebrae e do Ministério do Turismo. O programa visa melhorar a qualidade e competitividade de micro e pequenas empresas do setor turístico, contribuindo com o desenvolvimento sustentável nas áreas ambiental, econômica, social e cultural.

"A principal meta do PCTS é estimular os integrantes do turismo, inclusive o próprio turista, para que suas atividades sejam ambientalmente equilibradas, economicamente viáveis, socialmente justas, culturalmente ricas e politicamente legítimas". (www.pcts.org.br/pubpcts/cgi/cgilua.exe/sys/start.htm?sid=17). Segundo o site ainda, a certificação ambiental do turismo ajudará o país na competição acirrada que existe entre os destinos turísticos.

Com isso, pretende melhorar a imagem do Brasil como um forte destino no turismo internacional, desenvolvendo o Sistema Brasileiro de Normas e de Certificação em turismo sustentável.

Para tal, foi criada uma estratégia mobilizadora com participação ativa de vários atores da sociedade interessados no desenvolvimento do setor. O comitê Diretor do Programa foi montado com representantes do setor privado, dos trabalhadores e orga- 
nizações sociais, das organizações ambientais, do governo e instituições de fomento. Foi criada uma Comissão Técnica de Normas, para assessorar o comitê diretor nos assuntos relacionados aos temas de Normas e Certificação, e ainda a unidade executora do projeto.

A partir do estudo de diversas iniciativas no setor de certificação ambiental de várias partes do mundo, o CBTS desenvolveu suas diretrizes baseadas em várias outras consagradas e comumente aceitas. Com isso visa a integração nacional e reconhecimento internacional das iniciativas para o turismo sustentável, reconhecimento este que é obtido por meio do INMETRO junto ao "International Accreditation Forum" (IAF) e o "Sustainable Tourism Stewardship Council" (STSC). O programa consiste em desenvolver as normas para meios de hospedagem, o processo de certificação segundo essas normas e implementar um mecanismo de assistência às empresas do setor, objetivando:

- Propagar informações sobre boas práticas e novas tecnologias sustentáveis, almejar a conservação do meio-ambiente, a responsabilidade social, segurança e qualidade no setor turístico;

- Capacitar profissionais para prestar assessoria técnica às empresas (formação de multiplicadores);

- Fornecer subsídios para implementação de boas práticas sustentáveis em micro e pequenas empresas, desenvolvendo, publicando e disseminando manuais;

- Promover as empresas participantes e a imagem do destino Brasil Sustentável em mercados internacionais; 
Há ainda o Programa Bem Receber - Qualidade Profissional e Gestão Sustentável, que faz parte de uma estratégia de longo prazo para o desenvolvimento sustentável do setor turístico. O programa volta suas ações para a qualificação e certificação de pessoas e de empreendimentos, para aumentar a competitividade dos destinos atendidos pelo programa através do turismo sustentável.

2.2 Sustentabilidade \& Hotelaria

Para Serra (2006), sustentabilidade pode ser definida como o desenvolvimento que atende às necessidades da atual geração sem comprometer as necessidades das gerações futuras. Ele afirma também que o desenvolvimento só é sustentável quando são utilizadas fontes renováveis. Quando não existe a possibilidade de utilizar recursos renováveis, usa recursos não renováveis em tal ritmo que permita o desenvolvimento de sucedâneos.

As riquezas naturais são exploradas para produção de lucro, o que ignora os limites de exploração da terra e leva às grandes catástrofes ambientais. De acordo com Neiman (2002), quando são dadas todas as atenções ao mercado, este passa a ser o grande regulador do limite de exploração das riquezas naturais, o que constitui uma tendência mundial progressiva.

Atualmente existe uma crescente preocupação no setor hoteleiro com a questão ambiental. "O segmento hoteleiro mundial tem atuado nesta área, já há alguns anos, porém com enfoque fortemente na redução de custos e desperdícios" (RICCI, 
2002, p. 79). Fato esse que não é realmente ruim, porque consegue aliar dois fatores muito importantes para a hotelaria e turismo em geral: redução de custos e economia de recursos. Isto não significa que os hotéis não possam ter luxo ou conforto, ou que os hóspedes precisem estar no meio da mata para estarem preocupados em preservar a natureza.

Nos hotéis da Europa, desde a década de 80, utilizam-se técnicas para minimizar o uso de recursos naturais, como energia e água, por exemplo.

O hotel que pretende incluir a questão ambiental como prioridade para seu empreendimento, precisa contar com a atuação de um bom profissional hoteleiro e a necessidade de excelente seleção, recrutamento e treinamento da equipe de funcionários, aptos para lidar com as mudanças que a sustentabilidade exige.

A hotelaria deve se apropriar das inovações tecnológicas disponíveis que possam ser utilizadas no setor, como reciclagem de materiais, reutilização da água, sistemas combinados de eficiência energética, entre outras tantas soluções criativas.

Existe a norma ISO 14001, que nasceu em 1996 na Europa, e destina-se às empresas que, além de ter toda a qualidade que o selo ISO oferece, tem um enfoque específico na Gestão Ambiental. Seu objetivo é definir critérios para um sistema de gestão do meio ambiente, que seja efetivo e eficaz. Por ser considerada menos burocrática e mais prática que as outras normas já existentes, rapidamente ganhou força no mercado.

O sistema de gestão da sustentabilidade em desenvolvimento no Brasil alia-se aos demais modelos de sistemas de gestão estabelecidos, como a NBR ISO 9001 (sistema de gestão da qualidade), a NBR ISO 14001 (sistema de gestão ambiental) e a 
NBR ISO 14900 (sistema de gestão da análise de perigos e pontos críticos de controle, que trata da segurança alimentar).

\subsection{1 "Green Building" e Construção Sustentável}

As construções têm um grande impacto no meio ambiente, tanto enquanto estão em desenvolvimento, quanto depois de concluídas.

Como o mercado começou a voltar suas atenções para as questões ambientais, houve o surgimento de um novo conceito: o "green building", ou "construção verde", que surgiu na Europa e Estados Unidos a partir dos anos 70, a partir da conscientização da responsabilidade ambiental no momento de construir um empreendimento, para que se transforme em um espaço amigo do meio ambiente, dando origem assim à arquitetura sustentável.

Com a crise energética decorrente dos altos preços do petróleo no mercado internacional, os construtores passaram a pensar modos de se construir de forma mais amigável ao meio ambiente, com uso de fontes alternativas de energia, como a solar. Nos anos 1980, houve o ‘boom' dos sistemas de avaliação da performance ambiental dos edifícios, o que fortaleceu o movimento. (VIALLI, 2005)

Este conceito define as técnicas utilizadas para melhor utilização do solo, do projeto arquitetônico e melhor aproveitamento da construção em si, para reduzir o impacto ambiental. Na concepção da construção sustentável, o projeto deve ser encarado de forma holística, levando-se em consideração a construção e operacionalização do empreendimento, seu ciclo de vida, a economia e eficácia no aproveitamento de recursos e o bem-estar do usuário. 
O ideal é aplicar práticas que eliminem ou reduzam significativamente o impacto negativo ao meio-ambiente. Os aspectos mais comuns e importantes da construção verde são: eficiência energética, diminuição de emissão de gases, conservação e uso inteligente de recursos hídricos, diminuição de resíduos, diminuição do consumo de recursos naturais, desenvolver ambientes saudáveis e produtivos, reuso e reciclagem, prevenção da poluição da água, ar, solo e luz.

Os resultados positivos obtidos com a green building são vários, sob várias esferas: mercadológicos (argumento de venda, ganhos de imagem, publicidade sem custo), econômicos (menores custos de operação e manutenção, maior produtividade, valorização do imóvel), legais (diminuição de problemas com a legislação ambiental, diminuição das demandas trabalhistas) e sociais (responsabilidade social, ganhos ambientais).

Esta tendência é tão forte que no exterior as empresas se depararam com a situação de terem seus negócios prejudicados e até impedidos por não assumirem um compromisso de preservação ambiental. As pessoas hoje em dia estão mais interessadas se as empresas estão fazendo seu papel de preservar e proteger o meio ambiente. De acordo com Vialli (2005), é construir de maneira a ter o menor impacto ambiental e maiores ganhos sociais, sem, contudo, ser inviável economicamente.

Para Coimbra (2007), no futuro as casas e escritórios serão projetados para funcionar como organismos vivos, "especificamente adaptados ao local e capazes de suprir todas as suas necessidades de água e energia, a partir do sol, do vento e da chuva. A arquitetura do futuro vai se inspirar não nas máquinas do século 20, mas nas flores que crescem ao nosso redor". 
A China está criando a maior cidade ecológica do mundo, ao lado de Xangai, que deve ocupar uma área equivalente a $75 \%$ da ilha de Manhattan. A primeira fase ficará pronta logo em 2010. (SANTOS, 2007)

Não é exatamente uma novidade no ramo arquitetônico a construção ecologicamente correta: uma das grandes referências da atualidade em construção verde é o projeto das dez torres da sede do ING Group, no sudeste de Amsterdã, na Holanda. Essas torres abrigam mais de 2.500 funcionários, e foram construídas em 1987.

Para fazer um escritório funcionar de modo ambientalmente correto é mais do que fazer uma seleção de produtos certos. O projeto inicial em si, de que modo o empreendimento irá funcionar, são de fundamental importância. Cada vez mais os projetistas/ arquitetos dão atenção aos recursos que serão utilizados e como se dará seu descarte, entre outros critérios ambientais. Na Colômbia e na Costa Rica, bem como em países asiáticos, utiliza-se o bambu para substituir o concreto na construção de casas e até prédios. (COIMBRA, 2007)

Fatores como durabilidade, flexibilidade, consumo e conservação de energia são fundamentais para a arquitetura sustentável, de acordo com Serra (2006). O edifício deve ter caráter multifuncional, para evitar a necessidade de mais construções e extrações de materiais, que como a durabilidade, reflete-se também no tempo de duração da construção. "O uso de pedras para construir a Igreja de Santa Sofia pode ser considerado hoje um crime, mas esse é um dos edifícios mais sustentáveis do mundo, nunca foi refeito e sobreviveu a um sem número de terremotos e ataques". (SERRA, 2006) 
Para a arquitetura, a sustentabilidade em construções tem como metas minimizar: o consumo de materiais, a recorrência às jazidas naturais, o consumo de água e a produção de entulho. Por outro lado, deve-se maximizar a eficácia da construção e do abrigo.

Para isso, já existe uma série de tecnologias disponíveis para os arquitetos desenvolverem edifícios mais sustentáveis. O emprego de materiais naturais não quer dizer que o projeto seja sustentável. Segundo o Serra (2006), não devemos utilizar soluções "alternativas", mas sim as tecnologias disponíveis. "Uma casa toda de madeira pode ser menos sustentável que um edifício de aço". Porém, em várias construções civis ao redor do mundo, em lugares como Europa, Estados Unidos e Austrália, tem-se usado terra, bambu e madeira, por exemplo.

A eficiência energética do empreendimento deve ser ressaltada, de acordo com entrevista cedida pelo Prof. Marcelo Romero, chefe do Departamento de Tecnologia de Arquitetura da Faculdade de Arquitetura e Urbanismo da USP (SERRA, 2006). Os profissionais devem se utilizar das ferramentas disponíveis para reduzir o consumo energético. Segundo ele, o arquiteto tem o poder de diminuir em $27 \%$ o consumo com iluminação e $22 \%$ com ar-condicionado em edifícios comerciais, por meio de estratégias passivas (referente às envolventes exteriores), ativas (com a escolha de equipamentos) e pró-ativas (uso de turbinas eólicas, painéis fotovoltaicos, aquecedor solar, etc). Tudo isso visando baixo impacto a custos reduzidos.

O tipo de envolvente da construção influência diretamente na quantidade de carga térmica acumulada em seu interior. Quanto maior for a proteção opaca externa, com o uso de brises ou diminuindo a área envidraçada, menor será a carga térmica 
interna. Quando a fachada é totalmente envidraçada, implica no funcionamento excessivo do ar condicionado, e com isso se gasta muito mais energia.

Os benefícios são inúmeros. Menos consumo de energia, mais saúde para os ocupantes das construções e proteção para os ecossistemas.

Segundo o professor e pesquisador Vanderley John (apud VIALLI, 2005), da Escola Politécnica da Universidade de São Paulo, pode-se aumentar a contribuição com a sustentabilidade de qualquer empreendimento geralmente sem aumentar os custos do projeto: "as construções planejadas com esse viés podem ser mais caras, por adotarem novas tecnologias que ainda não têm escala. Mas, mesmo assim, trazem benefícios em redução dos custos de manutenção".

Edifícios com coleta seletiva de resíduos e aquecimento de água misto (energia solar e gás), de acordo com o presidente da Construtora Setin, Antônio Setin (apud VIALLI, 2005), possibilitam uma redução de custos de $80 \%$ se comparado aos custos de energia elétrica. O sistema de reuso de água, que faz com que a água dos chuveiros e lavatórios, após ser tratada, volte para abastecer os sanitários e as torneiras das áreas comuns, proporciona uma economia de água em torno de 35\%.

Esses gastos um pouco maiores com a implantação se mostram como um investimento, pois "um empreendimento com viés sustentável tem investimento de $5 \%$ a mais, que acaba sendo amortizado com a economia nos custos operacionais", segundo Setin (apud VIALLI, 2005).

Além disso, os projetistas buscam criar um ambiente de trabalho com mais qualidade. Por isso, a iluminação e qualidade do ar ganham cada vez mais importância em projetos inteligentes. Muitas empresas perceberam que a qualidade do ar interfere diretamente na produtividade e no número de faltas dos funcionários. Várias vezes o 
sistema de ar condicionado, de ventilação e dutos de ar estão em péssimas condições de manutenção, embora o ar esteja aparentemente bom e o ambiente limpo. Alguns materiais também podem emitir gases, que é o caso de certos móveis, carpetes ou outros produtos. Alguns fabricantes oferecem alternativas com compostos de baixa volatilidade.

Para a iluminação, atualmente existem no mercado vários componentes bonitos e eficientes no consumo de energia, que possibilitam fazer a escolha correta para o projeto. Lâmpadas especiais, abajures, filamentos ajudam a baixar o consumo. Ambientes regulados por controle automático ajudam a economizar, podendo ser desligadas de maneira automática rotineiramente. Uma tendência forte é não mais colocar vários pontos de luz como nos projetos mais antigos, e sim utilizar lâmpadas fluorescentes compactas em abajures, por exemplo, que economizam através da iluminação indireta, comumente usada na hotelaria de hoje em dia. Esse fator inclusive aumenta o nível de conforto percebido pelo hóspede.

Existe atualmente um uso crescente de produtos de escritório ambientalmente corretos, ao invés de produtos tradicionais. Essa troca resulta em um significativo efeito positivo sobre o meio ambiente.

A sustentabilidade na arquitetura também abraça o conceito da responsabilidade social e respeito às normas trabalhistas na contratação de mão-de-obra, às condições adequadas de segurança para trabalho e ao uso de materiais dentro da legalidade.

De acordo a Environmental Building News (in COIMBRA - com alterações), há uma lista de prioridades a serem consideradas para a Construção Verde: 
- Poupar energia

Projetar e construir edificações de baixo consumo, pois o consumo contínuo de energia é provavelmente o maior impacto ambiental que uma construção tem. Fatores importantes: isolamento térmico, janelas de alto desempenho, iluminação natural, recursos renováveis de geração de energia e equipamentos de baixo consumo.

- Reciclar construções existentes, aproveitando sua infra-estrutura em vez de ocupar novos espaços.

Muitas vezes as construções já existentes são fontes riquíssimas de recursos materiais e culturais. Em muitos casos, o trabalho e a qualidade dos materiais utilizados são praticamente impossíveis de se copiar, o que faz com que a restauração seja mais desejável ainda.

- Pensar comunitariamente

Considerar o transporte coletivo, e facilitar o trânsito de pedestres e bicicletas.

- Diminuir o consumo de material

Otimizar o projeto para aproveitar espaços reduzidos e utilizar materiais com mais eficiência. Quando se trata de insumo natural, é sempre melhor usar menos, desde que isso não comprometa a durabilidade ou integridade estrutural da construção. Diminuindo a área superficial da construção, irá diminuir o consumo de energia. Aproveitando bem o espaço e simplificando a geometria da edificação, poupa-se energia e materiais.

- Proteger e melhorar o local

Preservar/ restaurar o ecossistema e a biodiversidade. Em ecossistemas frágeis ou significativos, esta pode ser a prioridade. Proteger os mangues e outras áreas eco- 
logicamente importantes em uma parte da área que será construída. Nas áreas ecologicamente danificadas, procurar reintroduzir as espécies nativas. Proteger as árvores e a camada superior do solo durante a obra, e evitar o uso de pesticidas. Não despejar esgoto e agir com responsabilidade quanto aos detritos.

- Escolher materiais de baixo impacto

A maior parte do impacto ambiental causado pelo material de construção já aconteceu quando eles são utilizados. As matérias-primas foram extraídas do solo ou das florestas, os poluentes foram emitidos durante sua fabricação e energia foi gasta para a produção. Alguns materiais, como os que destroem a camada de ozônio, continuam poluindo durante seu uso. Outros materiais têm forte impacto ambiental no momento do descarte.

Evitar os materiais que geram poluição durante a fabricação; usar materiais de baixo consumo de energia na extração da matéria-prima, industrialização e transporte; dar preferência a materiais reciclados e evitar materiais que consomem recursos naturais limitados ou feitos com produtos tóxicos e/ou perigosos.

- Maximizar a longevidade

Projetar de maneira durável e que seja adaptável, pois quanto mais tempo dura uma construção, maior o período durante o qual o seu impacto ambiental pode ser amortizado. Para uma construção duradoura, deve ser pensado em possíveis necessidades futuras e de que forma a edificação pode ser modificada para se adequar a novas situações.

Escolher materiais duráveis, e construir de forma a evitar a decomposição prematura. Deve-se lembrar da manutenção e substituição de componentes menos durá- 
veis. O edifício deve ser adaptável, principalmente um edifício comercial. A estética deve ser considerada e o melhor estilo arquitetônico é o "atemporal".

- Poupar água

Projetar edificações de baixo consumo, instalando tubulações e equipamentos de baixo consumo. Coletar e utilizar água da chuva. Separar as chamadas "águas cinzas" (de pias e chuveiros) e reutilizar para a irrigação dos jardins.

- Tornar a construção saudável

Criar um ambiente interno seguro e confortável para seus ocupantes. Projetar o sistema de distribuição de ar para que a limpeza e manutenção se dêem de forma fácil. Evitar equipamentos mecânicos que possam introduzir gases de combustão. Controlar a umidade, a fim de evitar mofo. Evitar materiais que liberem poluentes. Permitir que a luz do dia penetre no maior número possível de cômodos. Providenciar ventilação contínua. Dar aos ocupantes algum controle sobre o ambiente, como o controle do aquecimento e da iluminação.

- Minimizar o desperdício de construção e demolição

Economicamente, a separação e reciclagem de materiais compensam bastante, pois reduzem o orçamento da obra. Separar os refugos de construção e demolição para reciclagem. Doar o material reutilizável para ONGs ou outro tipo de organização comunitária, para serem reutilizados.

- Deixar seu empreendimento verde

Minimizar o impacto ambiental de seu negócio. Divulgar o assunto; usar veículos de baixo consumo para a empresa, incentivar o uso do transporte público e a carona. Usar papel reciclável. Divulgar a consciência ambiental, educando clientes, colaboradores, colegas. 
Fonte: Environmental Building News - In COIMBRA. (com alterações) www.novomilenio.inf.br/real/ed090r.htm

2.2.2 Informações Interessantes

- $20 \%$ das novas casas, na Austrália, são de taipa de pilão.

- Na Califórnia, os mais ricos constroem mansões com técnicas semelhantes às utilizadas nas casas de pau-a-pique do interior do Nordeste.

- O estado de Nova lorque criou um programa de dedução de impostos para incentivar a construção de edifícios ecologicamente corretos.

Fonte: www.novomilenio.inf.br/real/ed090r.htm

- Metade da população mundial (mais de três bilhões de pessoas) enfrenta problemas de abastecimento de água. Muitas fontes de água doce estão poluídas ou já secaram.

- $97 \%$ da água existente no planeta é salgada (mares e oceanos), $2 \%$ formas as geleiras e apenas 1\% é água doce (lençóis subterrâneos, rios e lagos).

- Uma pessoa consome cerca de 250 litros em média, por dia, com água para beber, banho, higiene, comida, lavagens de louça e roupas, limpeza da casa, e plantas.

Fonte: www.mma.gov.br 
- O papel reciclado demanda um terço a menos de árvores para ser produzido e é $15 \%$ mais eficiente no consumo de energia.

- A tecnologia de tinta sólida oferece vantagens, já que esse tipo de impressão usa menos material que as impressoras a laser coloridas. A produção de resíduos é $90 \%$ menos. Para a impressão de mil páginas, a impressora colorida a laser gera $71 \mathrm{~kg}$ de resíduos. Se a impressão for feita com tinta sólida essa quantidade diminui para 1,8 kg.

- Reaproveitar materiais no próprio ambiente de trabalho é uma prática que qualquer empresa pode seguir. O processo vai desde a simples compra de produtos reciclados até a devolução de seus cartuchos de tinta vazios para fornecedores que oferecem serviços de reutilização.

Fonte: http://www.flexeventos.com.br/detalhe 01.asp?url=artigos green84.asp

\subsubsection{Boas Práticas}

Existem algumas ações práticas que já são utilizadas na hotelaria para redução de custos e melhor aproveitamento de recursos, poupando assim o meio ambiente. Os mais comuns são:

- Uso de redutores de vazão de água nas torneiras

- Uso de Economizadores de Energia nas UH

- Uso de Dispositivos de Presença (sensores)

- Uso de Lâmpada Econômicas

- Uso de Torneiras Automáticas 
- Reaproveitamento de Amenidades

- Sistema de Compostagem de resíduos

- Coleta Seletiva de Lixo Gerado nas UH

- Avaliação do Uso e Cuidados Especiais com PCB (Bifelias Policloradas)

- Tratamento Adequado de Efluentes Gerados

Pelo fato de o ramo hoteleiro ser bastante voltado para a excelência em servir e para as relações interpessoais de clientes internos (funcionários) e externos (hóspedes), o hoteleiro deve ser o profissional adequado para lidar com pessoas que tenham preocupação com o meio ambiente e querem estar em lugares onde também haja essa preocupação e respeito pela natureza. O PCTS prevê cursos e certificação para consultores e auditores, que serão formados multiplicadores do turismo sustentável no mercado brasileiro.

O Ministério do Meio Ambiente, juntamente com a Secretaria de Políticas para o Desenvolvimento Sustentável e o Instituto Brasileiro de Defesa do Consumidor (IDEC), relacionou algumas "dicas" de boas práticas para o consumo sustentável:

- ÁGUA

Somente agora o ser humano está se dando conta dos riscos que representam os esgotos, o lixo, os resíduos de agrotóxicos das indústrias para os mananciais. É imperativo cortar desperdícios para não ficarmos sem água em um futuro breve, e a água é a fonte da vida. 
Outras medidas que auxiliam na contenção do consumo de água são: instalar redutores de vazão em torneiras e chuveiros, instalar torneiras com aerador (peneirinhas ou telinhas nas saídas de água, que apesar de darem a sensação de maior vazão, fazem o oposto), inclusive na cozinha do hotel, torneiras com temporizadores, que desligam automaticamente. Durante a construção/reforma, dar preferência às caixas de descarga, ao invés de válvulas.

Ao lavar louça, utilizar bacia ou a própria cuba da pia para deixar pratos e talheres de molho por alguns minutos antes da lavagem. Isso ajuda a soltar a sujeira. Utilizar a água corrente somente para enxaguar. Se for utilizar máquina de lavar, ligar somente quando estiver com sua capacidade totalmente preenchida.

Roupas também devem ser deixadas de molho e usar a água corrente somente pra enxaguar. Utilizar pouco sabão, para evitar muitos enxágües, e a água após a lavagem pode ser aproveitada de alguma forma pelo hotel, para lavar a calçada, por exemplo, após varrer. Dar preferência às máquinas com abertura frontal, pois gastam menos água do que as com abertura superior.

Vazamentos são grandes responsáveis por desperdício de água. Podem ser evidentes, como uma torneira pingando, ou escondidos, no caso de canos furados ou de vaso sanitário. Para este último, o vazamento pode ser identificado jogando cinzas no fundo do vaso sanitário e observando por alguns minutos, Se houver movimentação da cinza ou se ela sumir, é porque há vazamento. Outra forma de detectá-los é através do hidrômetro (relógio de água), porém é necessário fechar todos os registros, exceto as saídas de água. Depois de algumas horas, caso haja alteração no número indicado no hidrômetro ou movimentação da circunferência do medidor, há vazamento. 
Para jardim e paisagismo, o ideal é cultivar plantas que necessitem de pouca água, como bromélias, cactos, pinheiros e violetas.

\section{- eNERGia ELÉTRICA}

O consumo de energia elétrica no Brasil aumenta, a cada ano. Comércios com alto padrão de consumo e a dinamização de atividades são grandes responsáveis por este aumento, porém o grande vilão continua sendo o desperdício. Os consumos residencial e comercial representam $42 \%$ do consumo total.

Na hora de comprar aparelhos eletrodomésticos, levar em consideração o selo PROCEL - Programa de Combate ao Desperdício de Energia Elétrica.

O chuveiro elétrico é um dos aparelhos que mais consome energia. O ideal é evitar seu uso em horários de maior consumo (de pico): entre 18h e 19h30, e no horário de verão, entre $19 \mathrm{~h}$ e $20 \mathrm{~h} 30$.

Ao escolher lâmpadas, dar preferência às fluorescentes, compactas ou circulares, para a cozinha, áreas de serviço, garagens, e outros lugares que não precisem de iluminação constante. Além de consumirem menos energia, essas lâmpadas duram mais que as outras.

Ao escolher as cores das tintas para tetos e paredes, é bom lembrar que cores claras refletem melhor a luz, reduzindo assim a necessidade de luz artificial.

Evitar acender lâmpadas desnecessárias durante o dia, aproveitando melhor a luz solar, abrindo janelas, persianas e cortinas. Desligar as luzes sempre que os ambientes estiverem desocupados. Instalar luz acionada por sensores de movimento é uma excelente alternativa. 
Em determinadas localidades, o aparelho de ar condicionado pode se tornar o vilão do consumo energético, por isso, no momento da escolha, o ideal é encontrar um modelo adequado ao tamanho do ambiente em que será utilizado. Dar preferência às marcas com melhor eficiência segundo o selo da PROCEL e com controle automático de temperatura. Na instalação, procurar proteger a parte externa da incidência de raios solares, porém sem bloquear as grades de ventilação. Enquanto o aparelho estiver funcionando, manter as portas e janelas fechadas e desligá-lo quando o ambiente estiver desocupado. Evitar o frio excessivo, regulando o termostato, e manter os filtros do aparelho sempre limpos, até para não prejudicar a circulação de ar.

Uma excelente alternativa para a economia com energia elétrica é a instalação de um boiler (aquecedor). Deve ser levada em consideração a possibilidade de instalação de energia solar. O ideal é colocar o aquecedor o mais próximo possível dos pontos de consumo, isolando com cuidado as canalizações de água quente.

\section{- LIXO}

Enquanto a água pode nos faltar, o lixo sobra. E ele aumenta tanto que não sabemos onde coloca-lo. Essa dificuldade é maior quando associada aos custos para se criar aterros sanitários. A situação torna-se pior quanto se constata que na maioria das cidades brasileiras o lixo é despejado em terrenos baldios ou lixões. Além de deixar os lugares mais feios, traz problemas nas épocas de chuva com entupimento de bueiros e estrangulamento dos corredores de água.

Em oposição a essas práticas incorretas, tem-se estimulado o uso de métodos alternativos de tratamento como a compostagem e a reciclagem ou, dependendo do caso, incineração. A incineração (queima do lixo) é a alternativa menos aceitável. Pro- 
voca graves problemas de poluição atmosférica e exige investimentos de grande porte para a construção de incineradores.

A compostagem é uma maneira fácil e barata de tratar lixo orgânico (detritos de cozinha, restos de poda e fragmentos de árvores). A reciclagem é vista pelos governos e defensores da causa ambiental como a solução para o lixo inorgânico (plásticos, vidros, metais e papéis). Com a reciclagem é possível reduzir o consumo de matériasprimas, a quantidade de lixo e a poluição.

É possível recuperar e reutilizar a maior parte dos materiais que no dia-a-dia são jogados fora. Latas de alumínio, vidros e papéis, facilmente coletados, estão sendo reciclados em larga escala em muitos países, inclusive no Brasil. Embora seja um processo em crescimento, ainda não é economicamente atrativo para todos os casos. Deve-se então evitar produzir lixo, reaproveitar o que for possível e reciclar o máximo.

Aproveitar integralmente os alimentos, variando o cardápio com o alto valor nutritivo de talos, folhas, sementes e cascas.

\section{METODOLOGIA}

A pesquisa foi elaborada principalmente com fonte em referências bibliográficas secundárias sobre Desenvolvimento Sustentável e sua aplicação na Hotelaria, mas também foram levantados dados sobre a prática de sustentabilidade por meio de questionários com gestores de meios de hospedagem de Brasília, com caráter ilustrativo 
para a pesquisa. Esses dados foram tratados de forma organizada de acordo com Dencker (1998).

O estudo também pretendeu mostrar os benefícios que a aplicação correta do conceito de Desenvolvimento Sustentável pode trazer à organização, reduzindo custos, aumentando o nível de satisfação dos hóspedes e poupando recursos naturais.

\subsection{Delineamento da pesquisa}

O projeto visou levantar os pontos positivos para a organização com a aplicação correta do conceito de Desenvolvimento Sustentável. Foram coletados dados em hotéis, para mostrar a diferença com a aplicação de conceitos de sustentabilidade na Hotelaria. Por esse motivo o projeto tem um cunho metodológico, onde são identificados procedimentos gerenciais considerados ideais para otimizar os serviços prestados aos hóspedes, aliados à preservação ambiental.

Os meios de realização da pesquisa foram bibliográficos, documentais (através de dados fornecidos pelos hotéis e outras instituições relacionadas ao turismo e ao meio ambiente) e de campo, com a aplicação de questionários aos gestores/ gerentes operacionais dos hotéis.

3.2 Área de interesse e população-alvo do estudo

A área de interesse é a de sustentabilidade aplicada à gestão hoteleira. Foram enfocados aspectos relacionados à gestão de recursos, a destinação de detritos e tra- 
tamento dos mesmos. Outro aspecto importante pesquisado é o papel do Gestor Hoteleiro na conscientização de clientes internos e externos, e quais os meios ele deve utilizar para obter os melhores resultados. A pesquisa de campo foi realizada no ambiente dos meios de hospedagem da cidade de Brasília, juntamente a gestores.

\subsection{Amostragem}

Foram coletados dados em hotéis da cidade de Brasília e experiências de outras localidades, que atendam a parcela da população com bom poder aquisitivo. Através de questionários respondidos pelos gestores/ gerentes operacionais, foi elaborada a análise sobre de que maneira os hotéis da cidade lidam com a questão do desenvolvimento sustentável na hotelaria.

\section{Questionário Tipo A - Hotéis tipo resort}

De acordo com a ABIH-DF, existem atualmente em Brasília quatro meios de hospedagem considerados resorts, que juntos somam $1.075 \mathrm{UHs}$, totalizando 1.846 leitos. Todos os quatro localizam-se às margens do lago Paranoá. Para a amostragem, foi analisado um único meio de hospedagem, pois foi utilizado o critério de $25 \%$ do valor total, porque o universo é reduzido (4); porém acima da porcentagem sugerida

\section{Questionário Tipo B - Hotéis Categoria 5 estrelas}


São nove os hotéis considerados padrão cinco estrelas pela ABIH em Brasília, que totalizam 2.004 UHs e 4.657 leitos. Dado o universo pequeno, foi analisada a amostra mínima de $25 \%$ do total.

\section{Questionário Tipo C - Hotéis Categoria 4 estrelas}

Segundo a $A B I H$, são treze os hotéis padrão quatro estrelas na cidade, porém são os que somam os maiores números de UHs e leitos: respectivamente, 2.810 e 6.027 . Também foi analisada a amostra de $25 \%$ do total.

\subsection{Instrumento de coleta de dados}

Foram coletadas informações através de documentação indireta (dados bibliográficos) e aplicados questionários com os gestores de meios de hospedagem da cidade classificados pela ABIH como resorts, 5 e 4 estrelas.

Consta em anexo o modelo do instrumento utilizado (questionário). Não houve diferença de perguntas entre os questionários Tipos $\mathrm{A}, \mathrm{B}$ e $\mathrm{C}$.

\section{ANÁLISES}

Os dados resultantes dos questionários foram tratados estatisticamente, e transformados em gráficos tipo pizza. Com o uso de estatísticas percentuais, busca-se a 
precisão dos resultados, com boa margem de segurança e a produção de informações úteis para o estudo do Desenvolvimento Sustentável da Hotelaria, como indicadores de resultados da aplicação de boas práticas do Desenvolvimento Sustentável para a Hotelaria.

Houve a exploração de aspectos qualitativos nos questionários com os gestores, onde foram observados fatores psicológicos. Algumas questões foram tratadas de forma conceitual, baseadas no posicionamento de cada gestor.

As informações obtidas com os gerentes gerais/ operacionais através dos questionamentos foram analisadas questão por questão, e tratadas da seguinte forma:

\subsection{Tipo(s) de energia utilizado(s) pelos hotéis}

O hotel considerado resort pela ABIH-DF utiliza dois tipos de energia, a elétrica e a solar, como pode ser visto na Figura 1. Com o sistema de boiler, o hotel consegue captar e armazenar energia solar para aquecimento da água, dentre outros. Quando não há sol por alguns dias, ou já se utilizou toda a energia solar armazenada, é acionado o uso da energia elétrica.

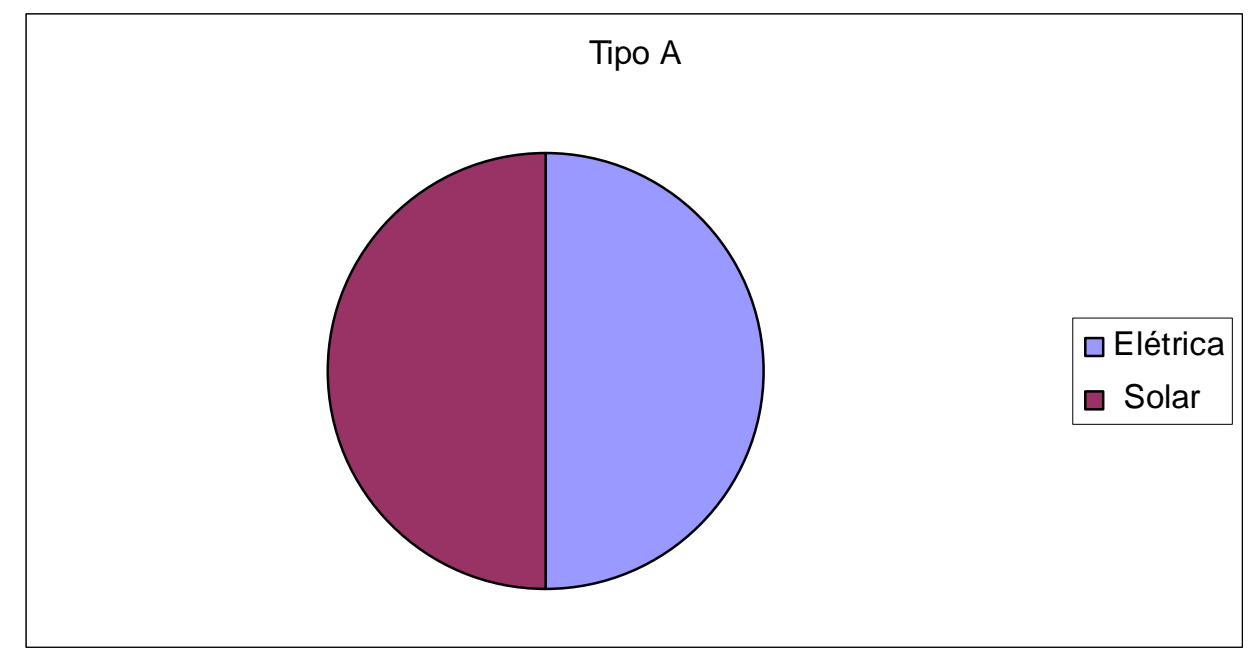


Figura 1. Gráfico Consumo de Energia Tipo A

Os hotéis do Tipo B, padrão 5 estrelas, em sua totalidade utilizam a energia elétrica. Porém dois deles utilizam uma segunda fonte de energia: um usa energia solar, e o outro, Gás GLP, de acordo com a Figura 2. Já nos hotéis padrão 4 estrelas, verificou-se que em $100 \%$ dos casos analisados os hotéis utilizam a energia elétrica como fonte de abastecimento, como mostra a Figura 3.

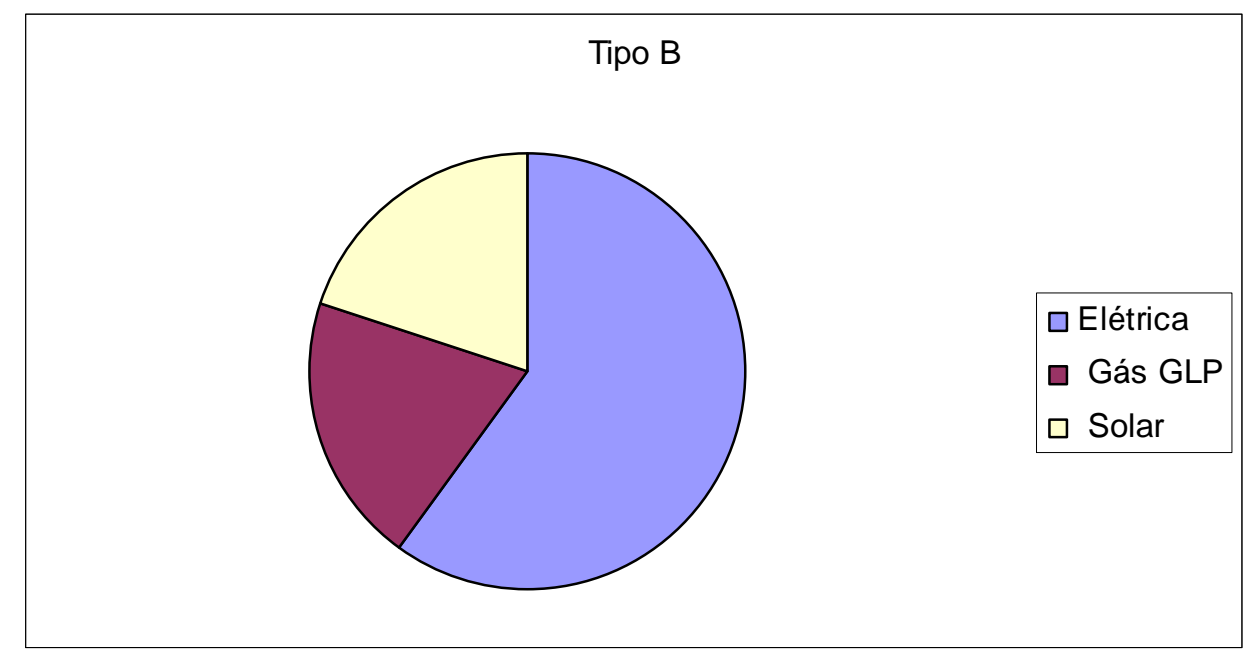

Figura 2. Gráfico Consumo de Energia Tipo B

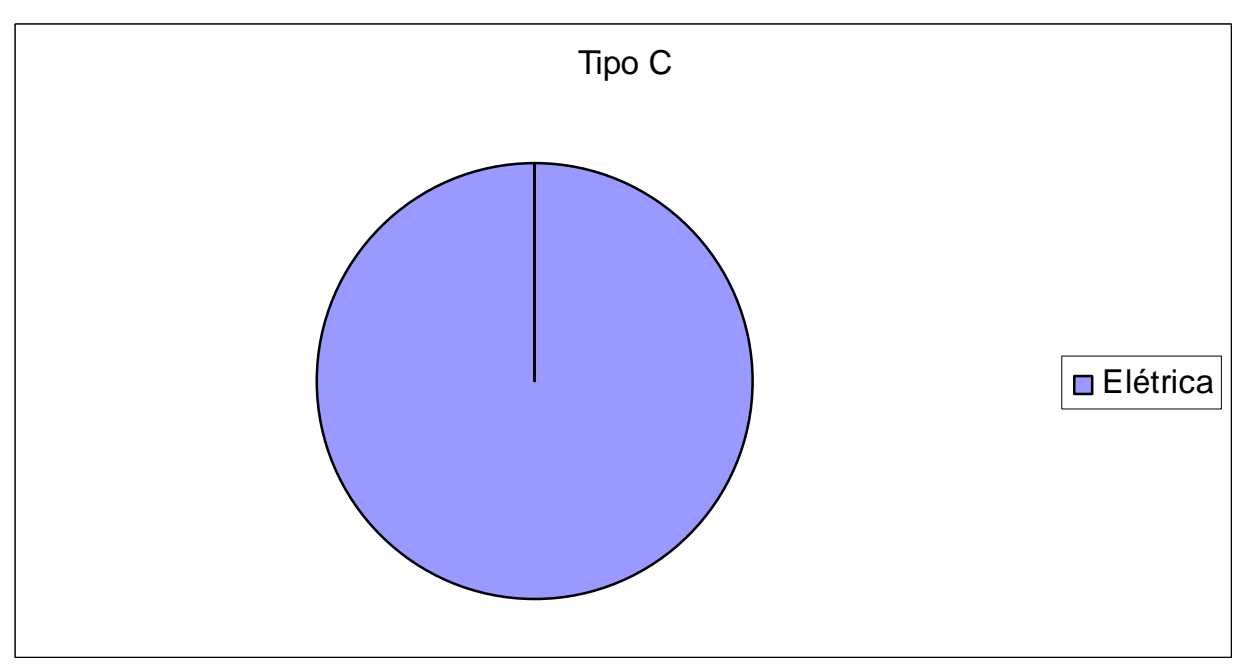


Figura 3. Gráfico Consumo de Energia Tipo C

\subsection{Existência de metas para consumo de energia dos hotéis}

Na segunda questão foi verificado se o hotel possui ou não metas mínima e máxima de consumo de energia. No questionário Tipo A, aplicado no resort, foi detectado que existe um controle do consumo, que é feito a partir do acompanhamento feito através de planilhas. Os outros meios de hospedagem, que também fazem acompanhamento e controle de consumo de energia também o fazem da mesma forma, através de planilhas de controle mensal.

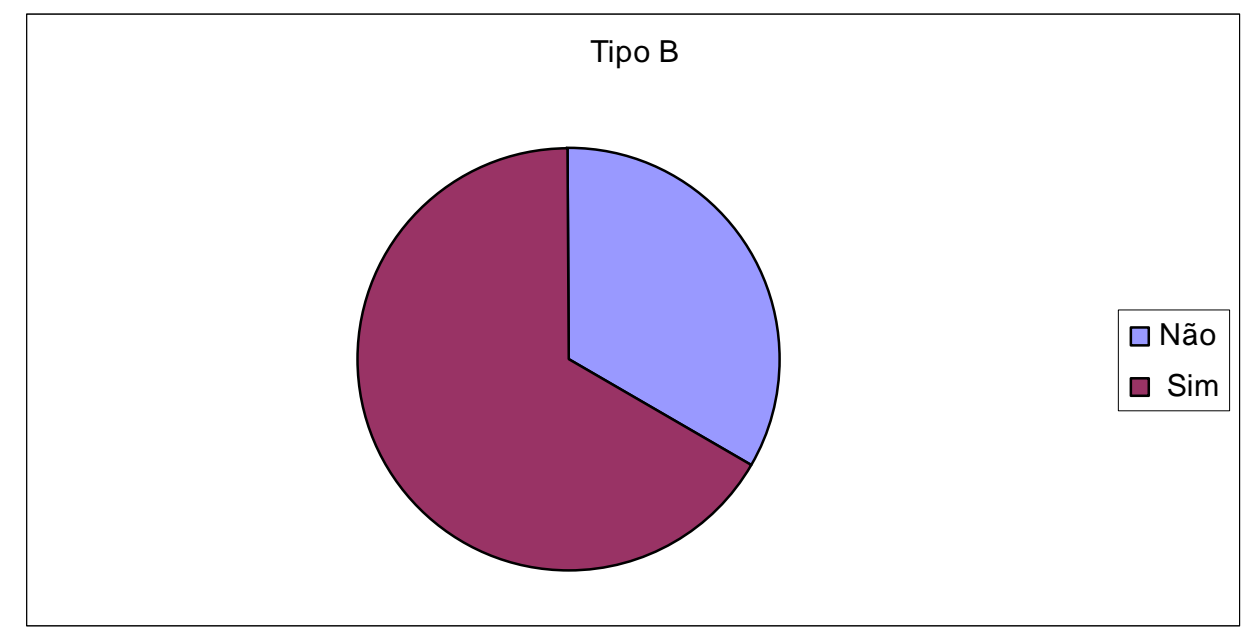

Figura 4. Gráfico Meta mínima e máxima consumo de Energia Tipo B

Nos meios de hospedagem Tipo B verificou-se que dois hotéis possuem algum tipo de controle para o consumo de energia, e um não possui, como mostra a Figura 4.

Nos hotéis tipo C, padrão 4 estrelas, metade dos hotéis pesquisados tem metas máxima e mínima de consumo de energia, como pode ser visto na Figura 5. Os que fazem este controle utilizam planilhas de acompanhamento de consumo como método. 


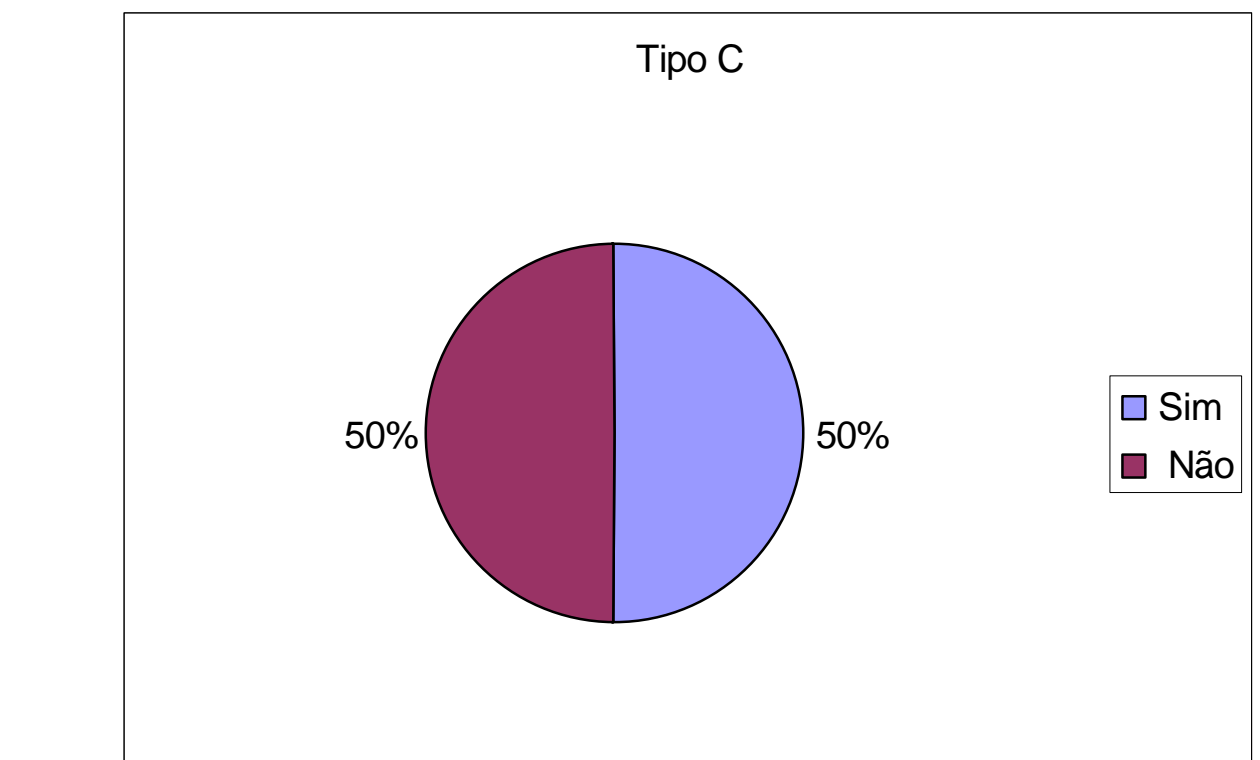

Figura 5. Gráfico Meta mínima e máxima consumo de Energia Tipo C

\subsection{Existência de sistema de coleta seletiva de lixo}

Em $100 \%$ dos meios de hospedagem pesquisados, entre os tipos A, B e C, obtevese como resposta que estes hotéis fazem coleta seletiva do lixo produzido.

\subsection{Reciclagem de materiais}

Segundo o questionário, o resort faz a separação de materiais destinados à reciclagem, como papéis, e também reutiliza internamente no hotel o lixo orgânico produzido, para servir de adubo para os jardins.

Vários hotéis utilizam o valor obtido com a venda de recicláveis para converter em benefícios para os funcionários, por exemplo.

Nos hotéis Tipo B, um não faz nenhum tipo de reciclagem de materiais, e os outros dois meios de hospedagem reciclam papéis e lixo orgânico, de acordo com a Figura 6, a seguir. 


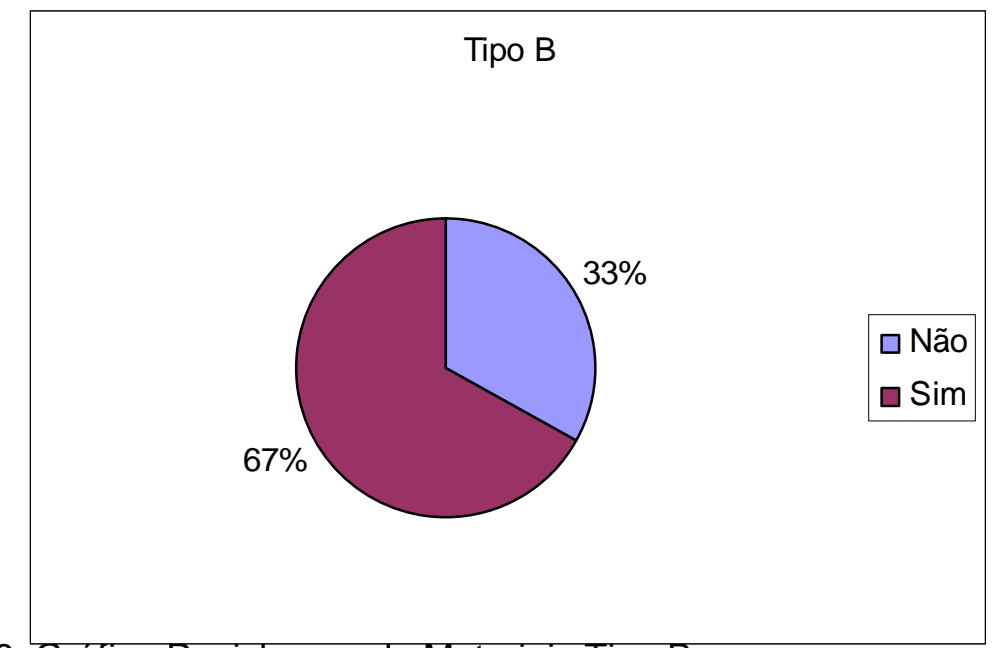

Figura 6. Grático Reciclagem de Materiais Iipo B.

Já nos hotéis Tipo C verificou-se que metade da amostra faz algum tipo de reciclagem de materiais, como mostra a Figura 7.

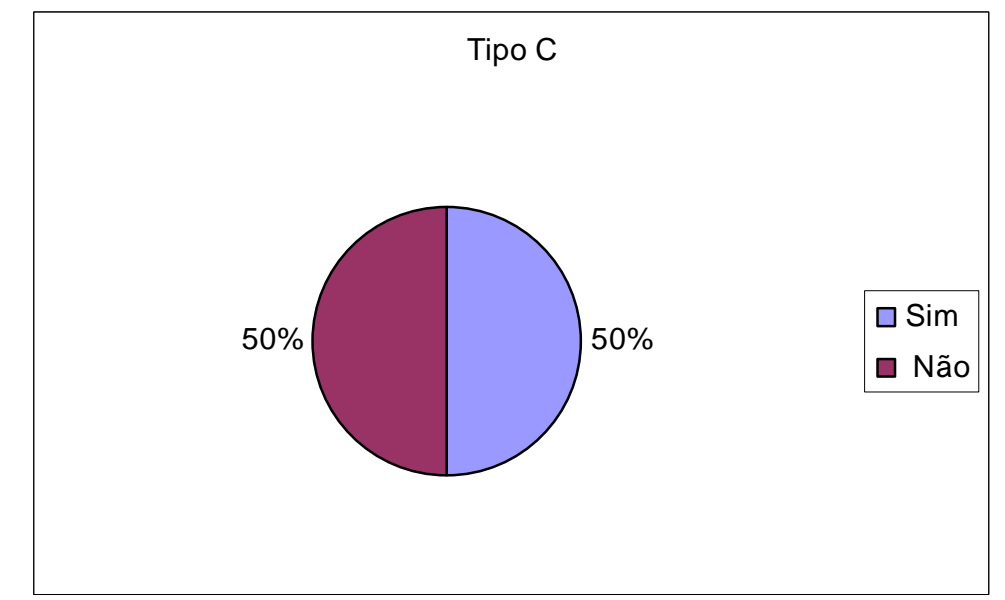

Figura 7. Gráfico Reciclagem de Materiais Tipo C.

\subsection{Reaproveitamento de água e gestão de seu uso}

De todos os meios de hospedagem pesquisados, nenhum deles possui algum sistema de reaproveitamento ou gestão do uso de recursos hídricos, o que é motivo de grande preocupação, pois a água é um dos principais recursos que deve ser preserva- 
do pelo homem. No âmbito local, a preocupação é ainda maior pelo fato da cidade de Brasília ser muito seca, fato este que reflete no consumo de água.

\subsection{Dispositivos para a economia de energia, água e outros insumos}

No hotel Tipo A, bem como em $67 \%$ dos hotéis Tipo B (Figura 8), são utilizados alguns dispositivos de economia de insumos: luzes com sensores de presença (poupadores de energia elétrica), redutores de água, torneiras com sensores e/ou temporizadores.

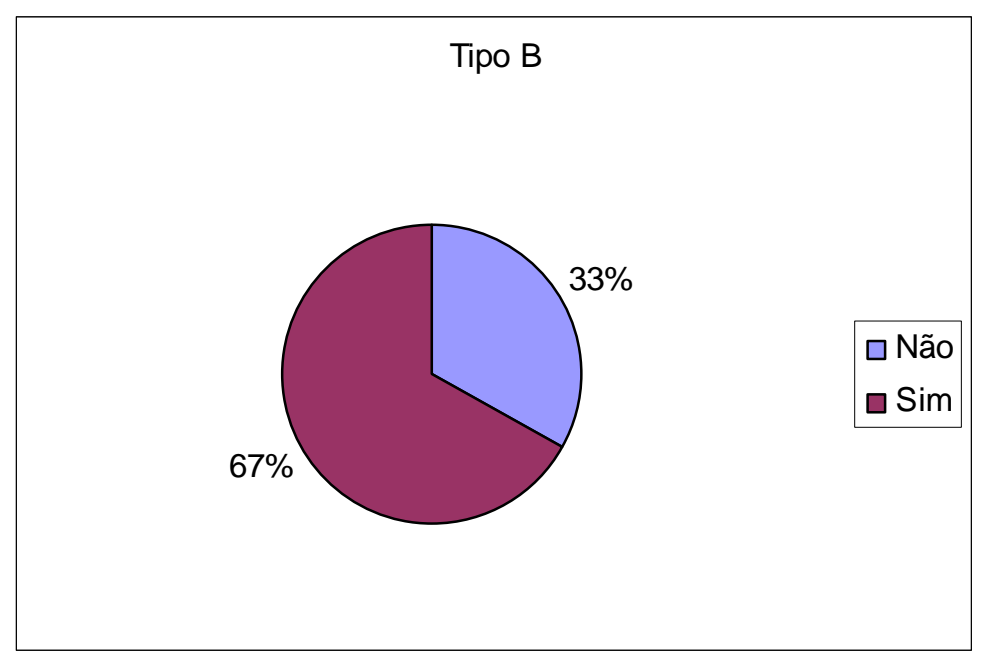

Figura 8. Gráfico Dispositivos para economia de insumos Tipo B.

$\mathrm{Na}$ análise dos meios de hospedagem Tipo C, foi verificado que $50 \%$ destes hotéis não utiliza nenhum dispositivo para a economia de água, energia e outros insumos, como pode ser visualizado na Figura 9. Os que possuem algum dispositivo contam com luzes acionadas por sensor de presença. 


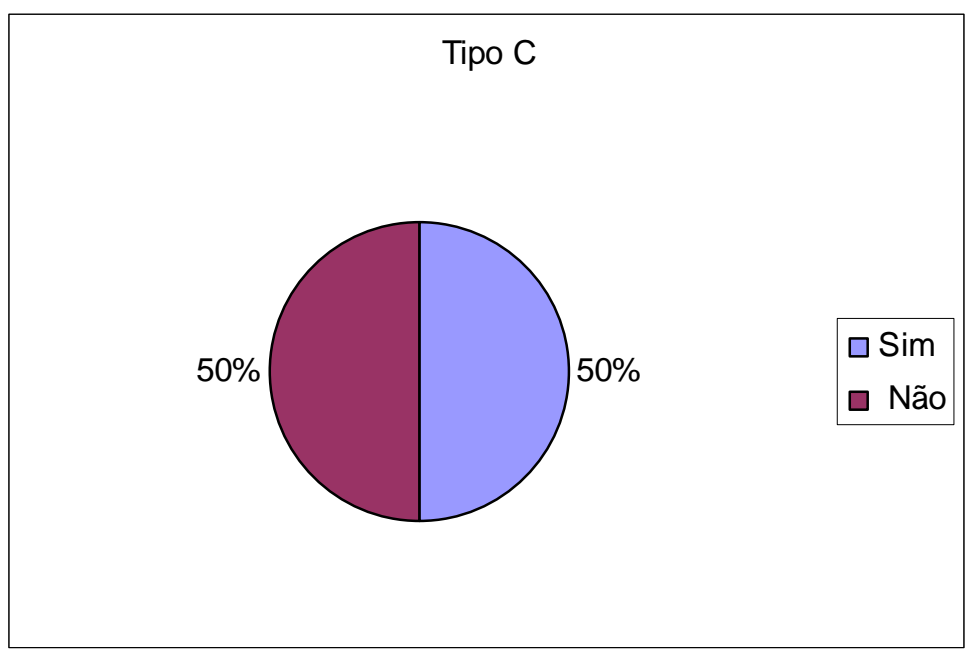

Figura 9. Gráfico Dispositivos para economia de insumos Tipo C

\subsection{Controle do uso de produtos e embalagens descartáveis}

Todos os meios de hospedagem analisados fazem algum tipo de controle de produtos e embalagens descartáveis. Muitos são coletados e destinados à doação, ou vendidos e convertidos em algum benefício para o próprio hotel, ou aos colaboradores, como cestas básicas, presentes em festa de fim de ano, etc.

\subsection{Tratamento especial para esgoto}

Segundo os questionários, todos os hotéis Tipo A e B possuem algum tipo de tratamento especial para o esgoto. Dentre as maneiras utilizadas informadas, estão as caixas de gordura tratadas com pó de rocha (bactérias), a dedetização e desratização, com aplicação de pó químico e líquido. Apenas um hotel Tipo $C$ não faz nenhum tipo de tratamento do esgoto que produz, como ilustra a Figura 10, a seguir. 


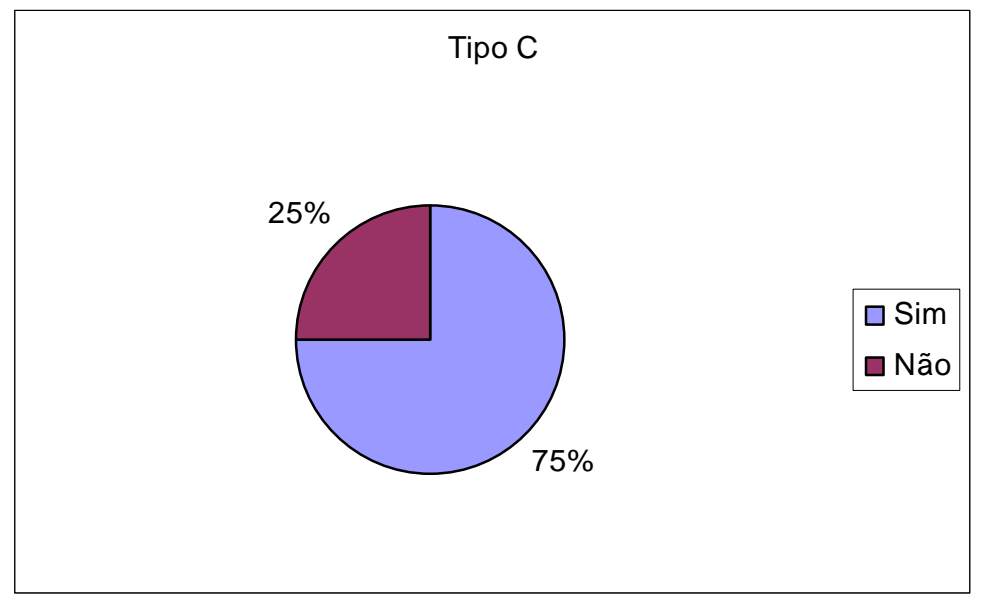

Figura 10. Gráfico Tratamento especial para esgoto Tipo C.

\subsection{Brigada de incêndio no hotel}

A brigada de incêndio é um quesito obrigatório para os hotéis, fundamental para a prevenção de acidentes e também para tomar as ações corretas em caso de acidente. Muitos hotéis utilizam funcionários do próprio quadro de colaboradores, que recebem treinamento para integrarem a brigada. O resort possui brigada de incêndio. Entre os hotéis Tipo B, um não possui (33\%), como mostra a Figura 11.

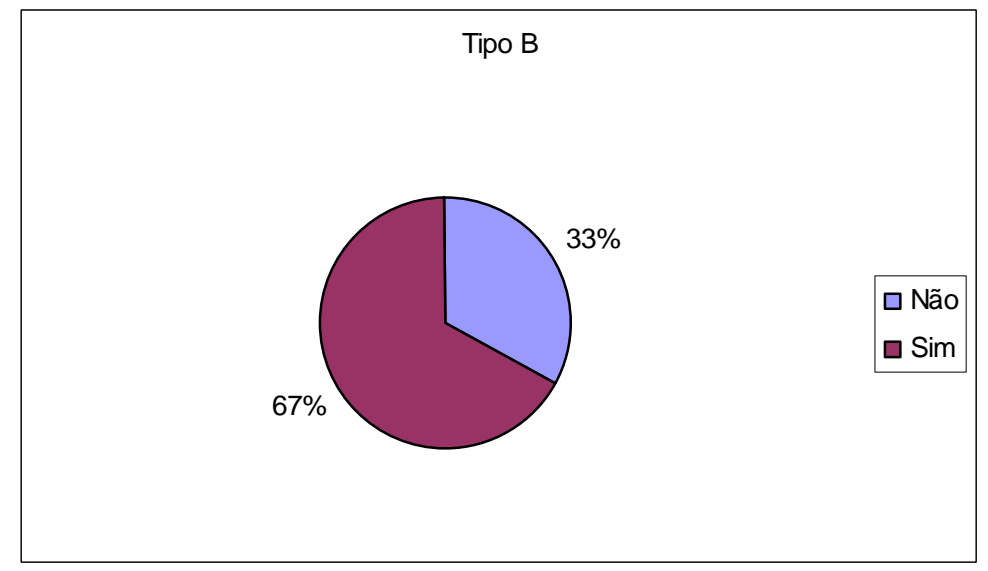

Figura 11. Gráfico Brigada de Incêndio Tipo B. 
Dentre hotéis Tipo C, verificou-se que metade da amostra (50\%) destes meios de hospedagem não possuem brigada de incêndio, como pode-se ver na Figura 12 a seguir.

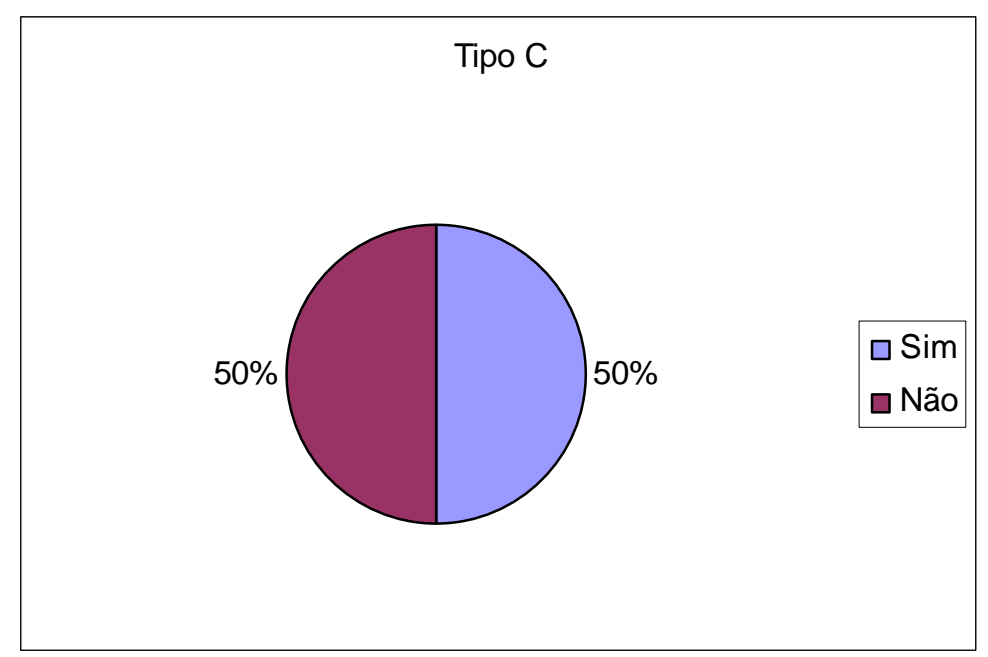

Figura 12. Gráfico Brigada de Incêndio Tipo C .

\subsection{Aquisição de produtos alimentícios para o hotel}

A aquisição de produtos alimentícios influencia principalmente em dois fatores: na qualidade dos alimentos servidos no hotel, e também no setor produtivo da comunidade local, gerando empregos e renda.

O ideal é comprar diretamente de produtores locais, sem agrotóxicos. Os produtos devem sempre chegar frescos ao hotel, e de preferência devem ser produtos orgânicos.

O meio de hospedagem Tipo A faz a aquisição de seus produtos por meio de tomada de preços, além de ter seu catálogo de fornecedores. Já os hotéis Tipo B utilizam vários modos diferentes entre tomada de preços, distribuidores autorizados, direto do fabricante ou por terceiros, dependendo do produto, como ilustra a Figura 13. 


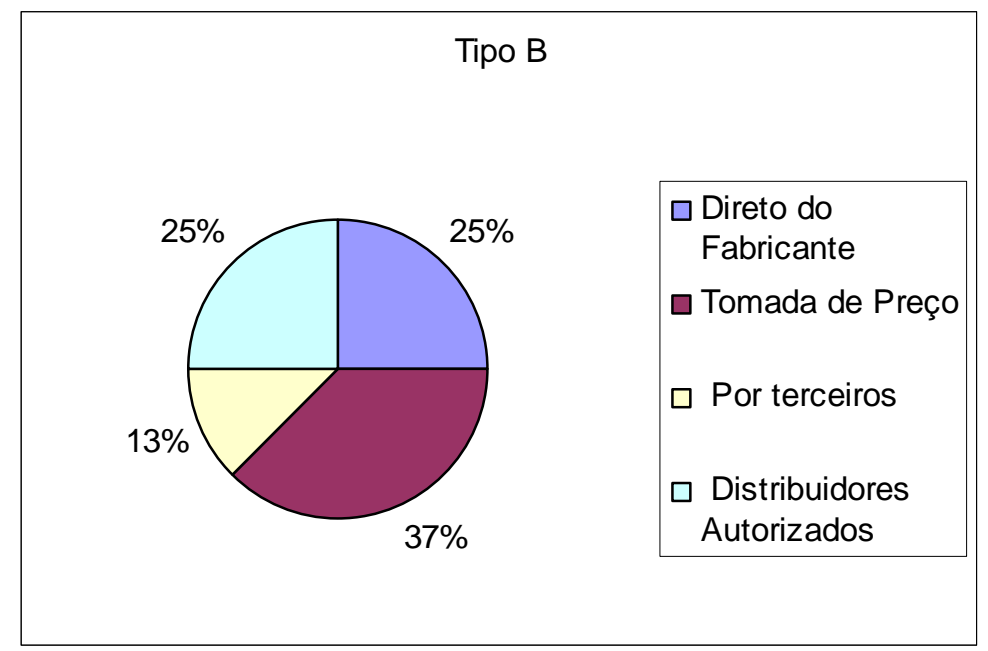

Figura 13. Gráfico Aquisição de Produtos Alimentícios Tipo B.

Dentre as maneiras utilizadas pelos meios de hospedagem Tipo $\mathrm{C}$, houve mais homogeneidade, e os processos de aquisição de alimentos são feitos de formas variadas, como pode ser visto na Figura 14.

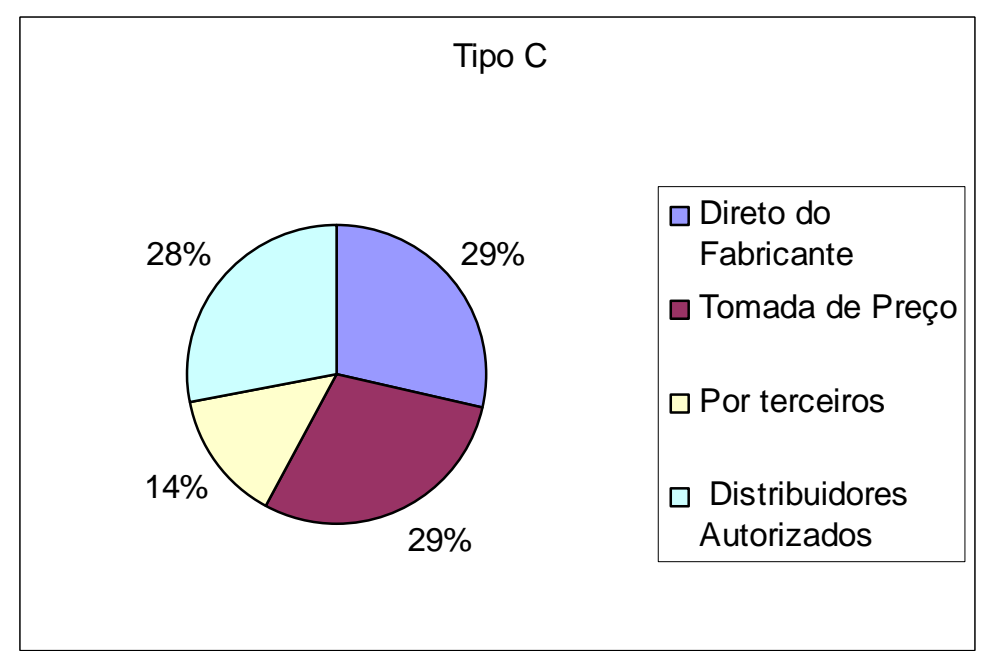

Figura 14. Gráfico Aquisição de Produtos Alimentícios Tipo C.

\subsection{Treinamentos para funcionários}

Todos os meios de hospedagem analisados oferecem algum tipo de treinamento para seus funcionários. Entre os mencionados nos questionários, estão: 
- Atendimento

- Manipulação de Materiais e Alimentos

- Implantação de Manual de Boas Práticas na Cozinha

- Higiene Pessoal, no local de trabalho e dos alimentos

- Boa postura e Apresentação

- Curso de Oratória (setor de vendas)

- Workshops (setor de vendas)

- Palestras Motivacionais (Administrativo)

- Excelência em Serviços

\subsection{2. Índice de satisfação dos hóspedes}

Segundo o resort, o índice de satisfação de seus hóspedes figura como ótimo, nos quesitos atendimento e qualidade dos serviços, e como bom quanto à infra-estrutura.

Nos hotéis Tipo B, apenas um avaliou os índices de satisfação dos hóspedes como bom nos três quesitos: Infra-estrutura, Atendimento e Qualidade dos Serviços. Os outros hotéis avaliaram como ótimo o índice de satisfação, como mostra a Figura 15.

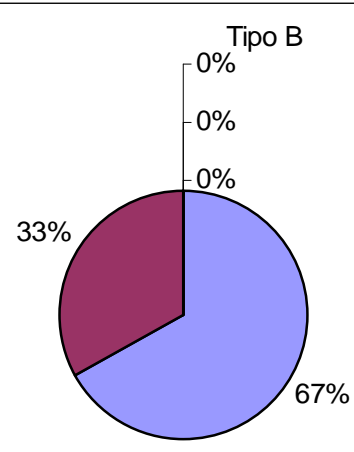

Figura 15. Gráfico Índice de Satisfação dos hóspedes Tipo B. 
Dentre os hotéis Tipo C, apenas um quesito de um hotel foi classificado como sendo bom (Infra-estrutura). Em todos os demais quesitos analisados, as respostas obtidas foram classificadas como 'ótimo'.

\subsection{Programa de envolvimento com a comunidade}

Os únicos meios de hospedagem que apresentaram algum tipo de envolvimento com a comunidade são os do Tipo C. Entre estes, a metade da amostra não possui nenhum tipo de envolvimento, como mostra a Figura 16. Entre os citados pelos hotéis, figuram a empregabilidade e o aproveitamento da cultura local.

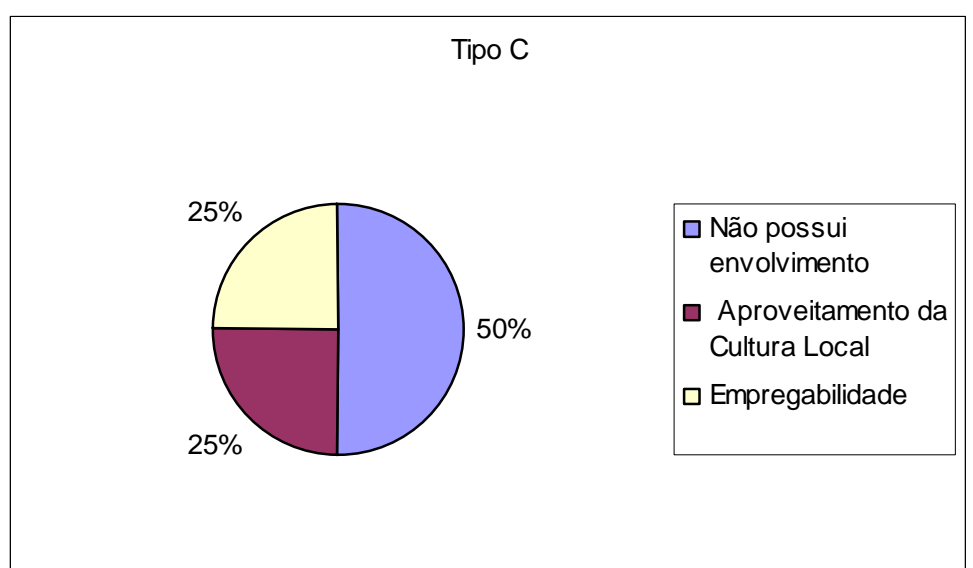

Figura 16. Gráfico Envolvimento com a comunidade Tipo C.

\subsection{Envolvimento com projeto ou organização ecológica}

Nenhum dos meios de hospedagem investigados dos Tipos A, B e C possui qualquer tipo de envolvimento com projeto ou organização ecológica. Nenhum dos hotéis pesquisados ainda percebeu a importância para o meio ambiente e para a imagem do meio de hospedagem. A organização também deve ter responsabilidade ambiental, além de social. 


\subsection{Inserção de aspectos culturais no hotel e seus serviços}

O resort insere em seu hotel e serviços aspectos culturais, na decoração, vestuário, paisagismo e na gastronomia, que, apesar de contar com um restaurante internacional, insere aspectos da culinária brasileira/ regional em seu cardápio.

Nos hotéis Tipo $B$, a inserção de aspectos culturais é mais variada, contando com mais opções, e ocorre da seguinte forma, de acordo com a Figura 17.

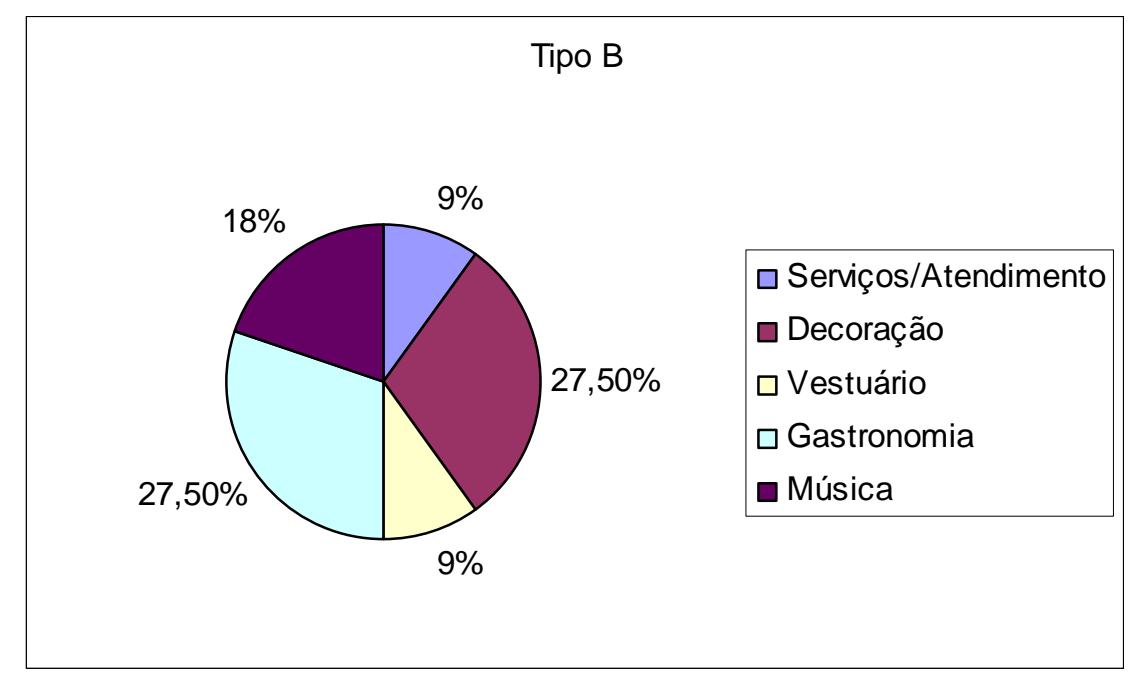

Figura 17. Gráfico Inserção Aspectos Culturais Tipo B

Nos hotéis Tipo C, o único aspecto cultural aproveitado é a gastronomia. Este fato configura nos questionários de todos os meios de hospedagem deste tipo.

\subsection{Visão sob o aspecto econômico da preservação dos recursos naturais}

A décima sexta pergunta do questionário é aberta, assim os gestores puderam expressar-se livremente sobre sua visão da conservação e preservação dos recursos naturais, sob o aspecto econômico. As respostas obtidas têm todas a mesma linha de 
raciocínio, onde a preservação do meio ambiente é fundamental para a existência do ser humano.

Algumas respostas:

- Compreendemos que é possível um desenvolvimento econômico que respeite e proteja o meio ambiente, a fim de continuar usufruindo das riquezas naturais.

- O aspecto econômico é essencial, porém não há economia sem a conservação do meio ambiente.

- Essencial para a sobrevivência da empresa e das pessoas.

- Progresso sem agressão ao meio ambiente. Otimização dos recursos naturais sem comprometer a capacidade de satisfazer as exigências das empresas e sociedade em geral.

- Deve haver sintonia com as atuais preocupações com as questões ambientais, mas também consciente das possibilidades tecnológicas aliadas ao planejamento e esforço conjunto das nações em preservas os recursos naturais.

\subsection{Classificação de importância}

Para o hotel Tipo A, bem como para todos os outros meios de hospedagem investigados, o setor financeiro é o mais importante. Os recursos humanos foram considerados o segundo mais importante item da organização, seguido por cultura, recursos naturais e comunidade. 
Nos hotéis Tipo B, o item financeiro foi considerado o mais importante (100\%), seguido pelos recursos humanos (100\%). Em terceiro lugar ficaram os recursos naturais (67\%), em quarto lugar a cultura (67\%) e em último lugar, a comunidade (100\%).

Nos Meios de Hospedagem Tipo $C$ foram unânimes as decisões dos $1^{\circ}$, $4^{\circ}$ e $5^{\circ}$ lugares. Respectivamente, financeiro, cultura e comunidade. Em $2^{\circ}$ e $3^{\circ}$ posições, os recursos Nnturais e humanos ficaram com $50 \%$ dos votos, cada um.

\subsection{Desenvolvimento Sustentável}

A última pergunta do questionário foi uma questão aberta, acerca do entendimento do gestor sobre Desenvolvimento Sustentável.

Algumas respostas:

- É desenvolver sem agredir

- Desenvolver sem comprometer as gerações futuras

- É o desenvolvimento capaz de suprir as necessidades da geração atual, sem comprometer a capacidade de atender as necessidades das futuras gerações.

- É o desenvolvimento que não esgota os recursos para o futuro.

- O desenvolvimento sustentável é uma das teorias ou filosofia mais importantes e urgentes do Séc. XXI. Ainda que seu conceito seja simples, a prática ainda é uma utopia. Sabemos que utilizar e preservar os recursos naturais que um país dispõe é muito mais coerente com o desenvolvimento econômico do que apenas beneficiar os interesses dos setores produti 
vos (comércio e indústria). A política mais correta seria conciliar as duas partes para atingir o objetivo pleno do desenvolvimento sustentável. Porém, cuidar da qualidade do meio ambiente não é um esforço que cabe apenas aos dirigentes, é uma questão de consciência global, de atitude comprometida de cada um de nós, por uma questão imperativa de sobrevivência. 


\section{CONSIDERAÇÕES FINAIS}

Atualmente existem vários fatores que estão mudando o futuro da indústria hoteleira. Pode-se considerar como um dos principais a preocupação com o meio ambiente e com a conservação do ecossistema, e de que forma o homem pode interagir reduzindo ao mínimo possível o impacto na natureza.

Para o setor turístico é fundamental a conservação do meio ambiente, pois é determinante para a atividade, que é desenvolvida no meio ambiente, e que consiste em um mercado em franca expansão.

Os meios de hospedagem têm sua responsabilidade com o meio ambiente desde o momento inicial, de sua construção, que além de materiais adequados, deve ter seu funcionamento ocorrendo de forma sustentável. Os hotéis, além de cumprirem com sua responsabilidade com a natureza, devem ser multiplicadores, conscientizando hóspedes e colaboradores, e levando a diante a preocupação com a conservação e preservação dos recursos naturais. Com isso, preserva o meio ambiente, reduz gastos, preserva a cultura local e a comunidade.

Com a pesquisa, verificou-se que o mercado hoteleiro de Brasília precisa atentar para a Sustentabilidade e suas aplicações na Hotelaria, pois os gestores ainda não perceberam a importância de ser sustentável. Todos os hotéis classificaram, por exemplo, o item financeiro como sendo o mais importante. Sua importância não pode ser negada, mas isso não pode ocorrer em detrimento de quesitos como recursos humanos e naturais, por exemplo.

Os hotéis da cidade ainda não "despertaram" para a questão sustentável, o que causa muita preocupação. Quesitos como brigada de incêndio são obrigatórios. 
A certificação ambiental é a melhor opção para agir em prol do meio ambiente e também ter diferencial competitivo no mercado.

Às vezes por falta de conhecimento uma simples medida fácil de ser tomada, que pode gerar economia para o hotel e benefício para o meio ambiente, não é realizada. $\mathrm{O}$ profissional do ramo hoteleiro é guiado pela prática, ignorando muitas vezes as melhorias provindas das inovações. Este profissional precisa perceber que as novidades disponíveis no mercado foram desenvolvidas para auxiliar.

O desenvolvimento tecnológico, que em grande parte foi responsável por toda a destruição que o meio ambiente já sofreu, será um forte aliado na conservação e no desenvolvimento sustentável, no âmbito da administração de meios de hospedagem, e do setor turístico em geral. 


\section{REFERÊNCIAS}

BELTRÃO, Otto di. Turismo: a indústria do século 21. Osasco : Novo Século, 2001.

BEM RECEBER. Programa Bem Receber: Qualidade Profissional \& Gestão Sustentável. Disponível em http://www.bemreceber.org.br/site/home/indexInt.php?id=1 Acesso em 30/06/2007.

BENI, Mário C. Análise Estrutural do Turismo. 5. ed. - São Paulo : SENAC, 2001.

CABRAL, Marcelo. A onda verde chegou aos escritórios. Disponível em http://portalexame.abril.com.br/revista/exame/edicoes/0886/gestaoepessoas/m0122182 html Acesso em 19/02/2007.

CHON, Kye-Sung (Kaye). Hospitalidade: Conceitos e Aplicações. Tradução: Ana Beatriz de Miranda. São Paulo : Pioneira Thomson Learning, 2003.

COIMBRA, Helô. Construção ecologicamente correta. Disponível em www.novomilenio.inf.br/real/ed090r.htm Acesso em: 27/01/2007.

CONSTITUIÇÃO 1988: Constituição da República Federativa do Brasil. Texto Constitucional de 5 de outubro de 1988 com as alterações adotadas pelas Emendas Constitucionais no 1/92 e 33/99 e Emendas Constitucionais de Revisão № 1 a 6/94. Ed. Atual em 1999. - Brasília : Senado Federal, Subsecretaria de Edições Técnicas, 1999.

DENCKER, Ada de Freitas. Métodos e Técnicas de Pesquisa em Turismo. São Paulo : Futura, 1998.

DUARTE, Vladir Vieira. Administração de Sistemas Hoteleiros: conceitos básicos. 2. ed. Ver. - São Paulo : Senac São Paulo, 2003.

GREEN BUILDING 84. Green Building: Todos são responsáveis. Disponível em http://www.flexeventos.com.br/detalhe 01.asp?url=artigos green84.asp Acesso em: 27/01/2007.

INSTITUTO DE HOSPITALIDADE. Norma Nacional para Meios de Hospedagem Requisitos para a Sustentabilidade. 2004. In

http://www.pcts.org.br/pubpcts/media/Norma IH Meios de Hospedagem.pdf Acesso em 25/11/2006.

LINDBERG, Kreg (org.). Ecoturismo: um guia para planejamento e gestão. 4. ed. São Paulo : SENAC São Paulo, 2002. 
MASLOW, Abraham H. Deborah C. Stephens (org.) Diário de Negócios de Maslow. Rio de Janeiro : Qualitymark, 2003.

MONTORO, Tânia S. (org.). Cultura do Turismo: desafios e práticas socioambientais. Brasília : Thesaurus, 2003.

NEIMAN, Zysman. Meio Ambiente: Educação e Ecoturismo. Barueri-SP : Manole, 2002.

RICCI, Renato. Hotel: Gestão Competitiva no Século XXI. Rio de Janeiro: Qualitymark, 2002.

RUSCHMANN, Doris Von. Turismo rural e desenvolvimento Sustentável. CampinasSP : Papirus, 2000.

SANTOS, Priscilla. Urbes do futuro: a primeira cidade ecológica do mundo é na China. Disponível em http://vidasimples.abril.com.br/edicoes/052/08.shtml Acesso em 27/01/2007.

SERRA, Geraldo. Palestra do 5ํㅡㄹ Encontro Regional ASBEA - Associação Brasileira dos Escritórios de Arquitetura. In Encontro esclarece conceitos e capacita arquitetos e empresas a desenvolverem projetos mais sustentáveis. 2006. Disponível em: http://www.asbea.org.br/eventos/seminario/enc con capacita arq.php?acao3 cod0=44 e8f52cafd3f047737fc9b4b5edfa3e Acesso em: 07/01/2007.

TOSTES, Ana Lúcia (org.). Educação Ambiental: curso básico a distância: educação e educação ambiental I. 2ª ed. Ampliada. Brasília : MMA, 2001.

VIALLI, Andréa. Construção Sustentável respeita o ambiente. In O estado de São Paulo. Disponível em:http://www.fsc.org.br/index.cfm?fuseaction=noticia\&IDnoticia=7. 2005. Acesso em: 07/01/2007.

WORLD TOURISM ORGANIZATION. Sustaintable Development of Ecotourism: A Compilation of Good Practices. WTO, 2001.

WESTERN, David. Como definir o ecoturismo. Em LINDBERG, Kreg (org.). Ecoturismo: um guia para planejamento e gestão. 4. ed. - São Paulo : SENAC São Paulo, 2002. 


\section{APÊNDICE A - QUESTIONÁRIO}

Hotel Tipo A

Cargo do pesquisado: Idade: Escolaridade: Sexo: ( ) F ( ) M

Questionário - Dirigido aos Gestores/ Gerentes Operacionais dos Hotéis

1. Qual(is) o(s) tipo(s) de energia utilizado(s) neste hotel?
( ) Elétrica
( ) Solar
( ) Eólica
( ) Outra. Qual:

2. Existem metas mínima e máxima para consumo de energia neste hotel?
( ) Sim
( ) Não

Em caso positivo, como é feita?

3. Existe um sistema de coleta seletiva de lixo?
( ) $\operatorname{Sim}$
( ) Não

4. O hotel faz algum tipo de reciclagem de materiais?
( ) $\operatorname{Sim}$
( ) Não
Em caso positivo, quais?

5. O hotel faz algum tipo de reaproveitamento de água, e gestão de seu uso?
( ) Sim
( ) Não

Em caso positivo, como?

6. Existem dispositivos para a economia de energia, água e outros insumos?
( ) Sim
( ) Não

Em caso positivo, como são utilizados? 
7. Existe controle do uso de produtos e embalagens descartáveis?

8. Há algum tratamento especial para o esgoto?
( ) Sim
( ) Não

Em caso positivo, como?

9. Existe brigada de incêndio no hotel?
( ) Sim
( ) Não

10. Como é feita a aquisição de produtos alimentícios para o hotel?
( ) Direto do Fabricante
( ) Por avaliações (tomada de preços)
( ) Por terceiros
( )

11. Quais treinamentos são dados aos funcionários do hotel?

12. Qual o índice de satisfação dos hóspedes em:

\begin{tabular}{|l|l|l|}
\hline \multicolumn{1}{|c|}{ Infra-estrutura } & \multicolumn{1}{c|}{ Atendimento } & Qualidade dos Serviços \\
\hline ( ) Ótimo & ( ) Ótimo & ( ) Ótimo \\
\hline ( ) Bom & ( ) Bom & ( ) Bom \\
\hline ( ) Regular & ( ) Regular & ( ) Regular \\
\hline ( ) Ruim & ( ) Ruim & ( ) Ruim \\
\hline ( )Péssimo & ( )Péssimo & ( )Péssimo \\
\hline
\end{tabular}

13. Existe algum programa de envolvimento com a comunidade?
( ) Empregabilidade
( ) Benefícios
( ) Aproveitamento da cultura local
( ) Outros. Quais? 
14. O hotel possui algum tipo de envolvimento com algum projeto ou organização ecológica? Em caso positivo, qual órgão? Que tipo de envolvimento?

15. Existe inserção de aspectos culturais da cidade/ estado/ país no hotel e em seus serviços?

( ) Serviços/ Atendimento

( ) Decoração

( ) Vestuário

( ) Gastronomia

( ) Música

( ) Flora/ Paisagismo

( ) Outros. Quais?

16. Sob o aspecto econômico, como o hotel encara a conservação e preservação dos recursos naturais?

17. Classifique de 1 a 5 , sendo 1 o mais importante para o hotel e 5 o menos importante
( ) Financeiro
Cultura
) Comunidade
) Recursos Naturais
) Recursos Humanos

18. Qual o seu entendimento sobre Desenvolvimento Sustentável? 


\section{ANEXO A}

\section{Tabela ABIH-DF - Classificação dos Meios de Hospedagem/DF}

\begin{tabular}{|l|l|r|r|}
\hline Hotel & Classificação & No UHs & \multicolumn{1}{l|}{ Leitos } \\
\hline Acadêmia de Tênis & $5^{*}$ & 220 & 500 \\
\hline Bonaparte & $5^{*}$ & 123 & 351 \\
\hline Carlton Hotel & $5^{*}$ & 195 & 420 \\
\hline Grand Bittar & $5^{\star}$ & 147 & 294 \\
\hline Kubistchek Plaza & $5^{*}$ & 289 & 800 \\
\hline Melia Brasília & $5^{*}$ & 256 & 512 \\
\hline Nacional & $5^{*}$ & 347 & 794 \\
\hline Naoum Plaza & $5^{*}$ & 187 & 402 \\
\hline Parthenon & $5^{*}$ & 240 & 584 \\
\hline TOTAL & & 2004 & 4657 \\
\hline Aracoara & $4^{*}$ & 131 & 262 \\
\hline Bristol Hotel & $4^{*}$ & 143 & 319 \\
\hline Comfort Suítes & $4^{*}$ & 187 & 346 \\
\hline Eron Hotel & $4^{*}$ & 181 & 371 \\
\hline Garvey & $4^{*}$ & 85 & 159 \\
\hline Manhattan Plaza & $4^{*}$ & 314 & 859 \\
\hline Meliá Confort & $4^{*}$ & 191 & 382 \\
\hline Mercure & $4^{*}$ & 330 & 660 \\
\hline Metropolitan & $4^{*}$ & 140 & 420 \\
\hline Phenícia Bittar & $4^{*}$ & 130 & 310 \\
\hline San Marco & $4^{*}$ & 256 & 562 \\
\hline St. Paul & $4^{*}$ & 340 & 573 \\
\hline St. Peter & $4^{*}$ & 382 & 804 \\
\hline TOTAL & & $\mathbf{2 8 1 0}$ & $\mathbf{6 0 2 7}$ \\
\hline Blue Tree Towers & Resort & 287 & 632 \\
\hline Blue Tree Park & Resort & 395 & 598 \\
\hline Bay Park Hotel & Resort & 240 & 310 \\
\hline Lake Side & Resort & 153 & 306 \\
\hline TOTAL & & 1075 & 1846 \\
\hline TOTAL & & 5889 & 12530 \\
\hline
\end{tabular}

Fonte: $\mathrm{ABIH} / \mathrm{DF}$ 


\title{
ANEXO B
}

\section{Artigo - Bambu, o material nobre da construção ecológica}

\author{
Por Helô Coimbra
}

De todos os materiais renováveis utilizados na construção ecológica, o bambu se destaca, por várias razões. Mas principalmente porque é um recurso renovável, com baixo custo de produção e pouco poluente. A partir do terceiro ano após o plantio, o bambu pode ser coIhido anualmente - uma árvore demora no mínimo 20 anos para poder ser aproveitada na produção de madeira ou carvão. A utilização do bambu como substituto da madeira pouparia milhões de árvores por ano e, além disso, ele pode ser plantado em áreas onde a agricultura é inviável.

O bambu cresce rapidamente e durante todo o ano. É muito ecológico e mais barato do que a madeira. Outra maravilha que pode ser feita com bambu é papel. A fibra é comprida e cresce depressa, além de ser mais forte do que a de eucalipto. O papel de bambu é mais resistente, e o custo da plantação por hectare é cinco vezes menor do que o custo da produção de eucalipto. Na construção ele também é melhor. Um poste feito com bambu defumado dura 70 anos, mais do que o eucalipto.

Além disso:

1. O bambu suporta mais tração em relação ao seu peso que o aço.

2. O carvão de bambu é eficaz na despoluição de rios e no tratamento de esgoto.

3. Na Colômbia, ele é utilizado para construir casas resistentes a terremotos.

4. Se o bambu desaparecesse de repente da face da Terra, aproximadamente $10 \%$ da população asiática ficaria desabrigada.

5. Cerca de 2 milhões de toneladas de broto de bambu são consumidos por ano.

6. O Brasil é o único país das Américas a ter uma grande indústria de papel de bambu, plantado principalmente no Maranhão.

7. $O$ bambu tem alta concentração de substâncias antioxidantes e cerca de $20 \%$ de proteína pura.

Em: www.novomilenio.inf.br/real/ed090r.htm 


\section{ANEXO C \\ Artigo - Urbes do futuro \\ A primeira cidade ecológica do mundo é na China Por Priscillla Santos}

Quem pensa que construção sustentável é uma casa de pau-a-pique no meio do mato está redondamente enganado. A China está levantando a primeira cidade ecológica do mundo. Dongtan irá ocupar uma área equivalente a três quartos da ilha de Manhattan ao lado do aeroporto da moderna Xangai. A primeira fase da empreitada deve ficar pronta em 2010 para abrigar, inicialmente, 50 mil pessoas - em 2040 deverão ser 500 mil. E nem pense numa vila povoada por hippies, mas sim em casas, hospitais, escolas e indústrias high-tech erguidas de forma sustentável. Até $80 \%$ do lixo sólido será reciclado, os ônibus serão alimentados por baterias elétricas, a água será reaproveitada e a energia elétrica, gerada por fontes alternativas. A comida virá quase toda das fazendas vizinhas. Casas e prédios terão suas telhas cobertas por gramados ou hortas para manter os lares frescos e absorver a água da chuva. Dongtan está na ponta-de-lança de uma tendência que ganha coro por todos os cantos do planeta, inclusive no Brasil. Em São Paulo, acaba de ser inaugurado o primeiro prédio sustentável do país para abrigar uma agência bancária. Mais dez edifícios no modelo já foram encomendados. É a preocupação ecológica batendo à porta dos cidadãos.

Em: http://vidasimples.abril.com.br/edicoes/052/08.shtml 